Supporting Online Material (SOM) for:

\title{
The status of the world's land and marine mammals: diversity, threat, and knowledge
}

\section{This PDF file includes:}

1. Data collection (inc. Fig. S1)

2. Analyzed data

3. Methods (inc. Figs. S2, S3)

4. Additional results (inc. Figs. S4 to S8; Tables S1 and S2)

5. References

6. Acknowledgements 


\section{Data collection: IUCN Red List Assessment of all mammals}

\subsection{Introduction}

For over four decades, IUCN (the International Union for Conservation of Nature, formerly the World Conservation Union), mainly through its Species Survival Commission (SSC), has been assessing the conservation status of species, subspecies, and populations on a global scale in order to highlight taxa at risk of extinction, and thereby promote their conservation. Today, the IUCN remains committed to providing the world with the most objective, scientifically based information on the current status of global biodiversity. IUCN disseminates information on the taxonomy, conservation status and distribution of taxa through the IUCN Red List of Threatened Species $^{\mathrm{TM}}$ (www.iucnredlist.org), currently updated on an annual basis.

As part of IUCN's efforts to rapidly expand the taxonomic coverage of the IUCN Red List, and to provide a core set of supporting documentation to underpin the IUCN Red List assessments (1), IUCN, in collaboration with several key partners, pioneered a series of global, comprehensive species assessments that provide an effective method for gathering, synthesizing, reviewing and disseminating the most accurate scientific data available for biodiversity conservation. To date, comprehensive species assessments have been completed for, among others, all of the world's amphibians (2) and hermatypic reefbuilding corals (3). Assessments are ongoing for many other taxa.

The current dataset on mammals is the product of a similar initiative to undertake a global, comprehensive assessment of the conservation status of all mammalian species. Prior to this assessment, the last time all mammals were assessed globally was in 1996 (4), and the majority of those assessments are out-of-date. Although the primary objective of the current initiative was to place each mammal species in a category of threat using the IUCN Red List system (5), the overall product includes a suite of supporting information, incorporating data on distribution, population numbers and trends, habitat, 
life history, threats, conservation actions, conservation status, and utilization for each individual wild mammal species. The resulting data, covering 5488 species (includind Homo sapiens), are the culmination of a systematic collection and documentation process conducted over a period of nearly five years (2003-2008), involving a partnership of numerous institutions, universities and museums, reviewed at 28 workshops, and the participation of more than 1,700 experts.

\subsection{Data compilation}

The assessment process comprised two core components: one centered around consultation with IUCN SSC Specialist Groups and stand-alone Red List Authorities, and another involving peer-review through workshops.

The IUCN Species Survival Commission is an established knowledge network of $\sim 8,000$ volunteer members working in almost every country of the world. SSC members are deployed in more than 120 Specialist Groups and Task Forces, with some 2,000 members being part of the mammal Specialist Group network. Currently, there are 29 Specialist Groups with a taxonomic focus on mammals (6), and one stand-alone Red List Authority (Small Nonvolant Mammal Red List Authority).

Relative to other taxa, the existing Specialist Group structure for mammals is remarkably strong for certain groups, with many having produced at least one IUCN SSC Action Plan in the last decade (7). Consequently, in cases where species were within the jurisdiction of well-coordinated groups, they were, as far as possible, assessed and reviewed by the members of these groups (as part of core Specialist Group activities).

In contrast, the SSC network is somewhat less developed with regard to small mammals, given that these contribute the overwhelming diversity of species (for example, more than one-half of all mammals are rodents). In such cases, we employed a workshop methodology, to provide a platform for discussion, interaction, and group peer-review of species relationships, life-history data and distribution maps. Workshops have proven to be most productive in terms of collating the greatest amount of species-based information 
within a relatively short time period. For the purpose of conducting careful detailed review of all mammal assessments, we conducted a series of 28 workshops in 18 countries around the world (and usually in collaboration with existing Specialist Groups):

1. Africa (Small Mammals) - January 24-30, 2004 (United Kingdom)

2. South Asia (Non-volant Small Mammals) - February 9-15, 2004 (India)

3. Southeast Asia (initial assessment workshop) - May 3-7, 2004 (Thailand)

4. Africa (Small Mammals, maps only) - August 22-26, 2004 (United Kingdom)

5. Philippines (initial assessment workshop) - November 2-3, 2004 (United States)

6. Edentates - December 17-18, 2004 (Brazil)

7. African Primates - January 26-30, 2005 (United States)

8. Madagascar - April 4-8, 2005 (Madagascar)

9. Sirenia - August 1, 2005 (Japan)

10. Japan - August 6-8, 2005 (Japan)

11. Australia/Pacific - August 15-19, 2005 (Australia)

12. Brazil and Guyanas - October 16-19, 2005 (Brazil)

13. Mongolia - October 31 - November 4, 2005 (Mongolia)

14. Southwest Asia - November 22-25, 2005 (Turkey)

15. Andes (Small Mammals) - February 6-10, 2006 (Colombia)

16. Asian Squirrels - March 27-29, 2006 (India)

17. Philippines - April 9-10, 2006 (Philippines)

18. Southeast Asia (Large Mammals and Bats) - May 2-6, 2006 (Indonesia)

19. Southeast Asia (Rodents) - May 2-5, 2006 (United States)

20. Europe - May 18-22, 2006 (Austria)

21. Old World small Carnivores - July 3-7, 2006 (Vietnam)

22. Asian Primates - September 7-12, 2006 (Cambodia)

23. Cetaceans - January 22-26, 2007 (United States)

24. Southern Cone - October 8-12, 2006 (Brazil)

25. Cats - September 21-22, 2007 (United Kingdom)

26. Mediterranean Mammals - October 9 - November 2, 2007 (Spain)

27. Neotropical Primates - November 28 - December 02, 2007 (United States)

28. Mesoamerica and the Caribbean (Small Mammals) - January 25-30, 2008 (Honduras) 
Prior to the workshops, data were collected by teams of researchers who relied on the available literature to document the current state of knowledge. In some cases, enormous amounts of information are available, but in the case of most species very little is known even about the basic ecology of a species in the literature. The documentation in the species accounts reflects this inequality.

During each workshop, invited species experts (including persons with both taxonomic knowledge as well as knowledge of threats "on the ground") were brought together to: 1) build consensus on the state of knowledge of the species; 2) fill in the knowledge gaps with both published and unpublished data; and 3) review maps of species distribution. Once complete, and under the guidance of facilitators trained in the use of the 2001 IUCN Red List Categories and Criteria (5), experts evaluated each species against a variety of thresholds for geographic range size, population size and rates of population reduction to make an assessment of extinction risk. Following each workshop, the entire set of supporting documentation was subject to final checks, while all IUCN Red List assessments were evaluated against the supporting data during a series of consistency checks (to ensure both the proper use of the categories and criteria and that supporting evidence was provided accordingly).

\subsection{Data collected}

For the first time, comprehensive, peer-reviewed data on the distribution, abundance, population trends, ecology, habitat preferences, threats, conservation status, utilization, and conservation actions for all 5487 currently recognized wild mammal species are available. Each species has also been coded according to the IUCN Habitats and Threats Classification Schemes, making it possible to analyze, for example, their habitat preferences and major threats. More specifically, the following data were collected on each species: 


\section{Systematics}

For each species, data were was collected on species, genus, family, order, taxonomic authority, commonly used synonyms, English and other common names (if any), and taxonomic notes (if needed, normally used to clarify difficult or confusing issues).

We used the $3^{\text {rd }}$ edition of Mammal Species of the World - A Taxonomic and Geographic Reference (8) as the taxonomic framework. However, as the text for this authoritative work was effectively completed in 2003, it has been necessary to depart from this standard lexicon in well-justified circumstances. In such cases, and except in very exceptional circumstances, any newly recognized species (either newly described or newly split) or any other proposed taxonomic change had to be published in a peerreviewed journal or other authoritative taxonomic work (e.g., a major faunistic treatise). As noted later, our classification is current as of December 2007; some recently proposed changes (e.g., 9, 10) are not accommodated.

Although the IUCN Red List is not intended to be a definitive taxonomic source, it strives to be taxonomically coherent and consistent at all ranks. Our higher-level classification largely follows that of Mammal Species of the World, but again deviates in some respects. At the level of Order, for example, the primary deviation is recognition of the Cetartiodactyla, to include the previously recognized orders Cetacea (whales, dolphins and porpoises) and Artiodactyla (bovids, hippos, giraffids, deer and relatives) (e.g., 11 16). While a case can be made for continuing use of the name Artiodactyla for this clade (17), we have decided to use the now established Cetartiodactyla to avoid confusion.

\section{General information}

General text information was compiled on: geographic range; population (usually a qualitative assessment of abundance or rarity in the absence of quantitative information); habitat and ecology (including, in particular, habitat preferences and ability to adapt to anthropogenic disturbance, as well as any particular biological traits that may render a 
species particularly vulnerable); threats; and conservation actions (in particular noting occurrence in protected areas).

\section{Distribution maps}

As part of the minimum supporting documentation for completing an IUCN Red List assessment, we mapped the distributions of each mammal in ESRI shapefile format (ArcView GIS 3.x and ArcGIS 9.x). The maps take the form of broad polygons that join known locations. A species' distribution map can consist of more than one polygon where there is an obvious discontinuity in suitable habitat. For some range-restricted taxa, we have tried to map distribution ranges with a higher degree of accuracy, sometimes down to the level of individual subpopulations. Individual polygons are coded according to species' presence (e.g., extant, possibly present, extirpated) and origin (e.g., native, reintroduced).

Of the 5,488 mammals for which we undertook an IUCN Red List assessment, we were able to map the ranges of 5,395 species (maps are missing for Extinct species and typically for some Data Deficient species, such as those known from non-specific type localities). These spatial data used the maps collected by W. Sechrest (18) as a starting point for part of the species, significantly improved in accuracy and detail through expert editing.

A list of countries of occurrence is coded, noting whether or not it is native extant, extirpated, introduced or re-introduced.

\section{Habitat preferences}

Each species is coded against the IUCN Habitats Classification Scheme (19)

\section{Major Threats}

Each species is coded against the IUCN Threats Classification Scheme (20). 


\section{Conservation Actions}

Each species is coded against the IUCN Conservation Actions Classification Scheme (21).

\section{$\underline{\text { Utilization }}$}

Each species is coded against the IUCN Utilization Classification Scheme (22) (focusing on the purpose/type of use, the primary forms removed from the wild, and the source of specimens in commercial trade). Species that are listed on any of the CITES appendices are also indicated.

\section{IUCN Red List Assessment}

Based on the information above, we used the 2001 IUCN Red List Categories and Criteria (Version 3.1) (5), to undertake an assessment of extinction risk for each mammal species. The IUCN Red List Categories and Criteria are the most widely accepted system for classifying extinction risk at the species level (1, 23-25), and as noted above have already been used in several other global assessments to date (2, 3). The IUCN Red List Categories include eight different categories of threat (Fig. S1): Extinct (EX), Extinct in the Wild (EW), Critically Endangered (CR), Endangered (EN), Vulnerable (VU), Near Threatened (NT), Least Concern (LC) and Data Deficient (DD). A species qualifies for one of the three threatened categories (CR, EN, or VU) by meeting a critical threshold for that category in one of the five different available criteria (A-E). The criteria are designed to be objective, quantitative, repeatable, and to handle uncertainty. 


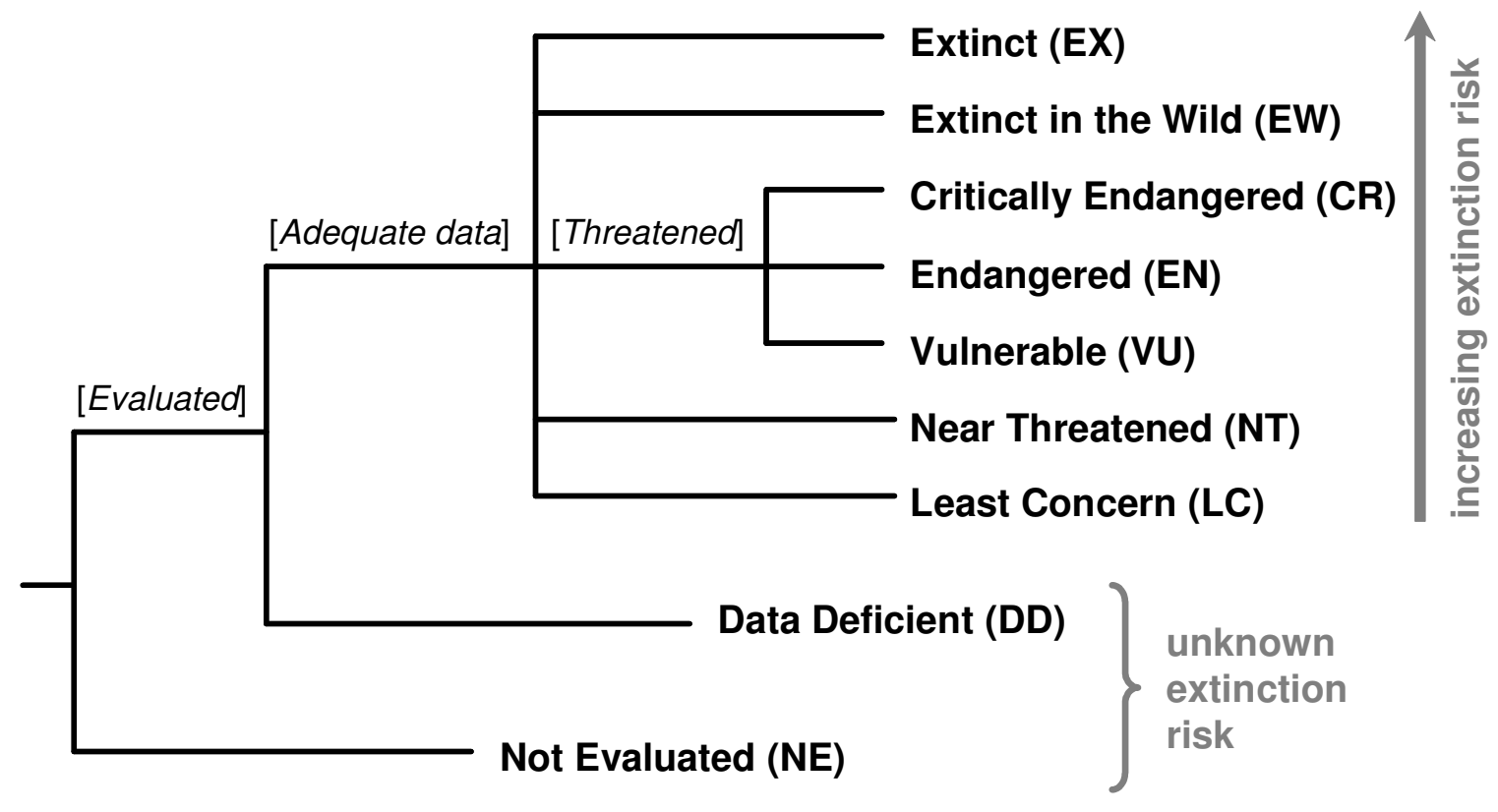

Fig. S1. The IUCN Red List categories. Adapted, with permission, from (5).

Each IUCN Red List assessment is accompanied by a rationale that explains how it was justified, the reason for any change from previous assessments (i.e., genuine change in species' status, or non-genuine due to new or better information available, incorrect information used previously, taxonomic change affecting the species, previously incorrect application of the IUCN Red List Criteria), the current population trend (i.e., increasing, decreasing, stable, unknown), date of assessment, names of assessors and evaluators, and any notes relating to IUCN Red Listing (e.g., any important issues in deciding the category).

Assessments are done at the species level, integrating the information across all populations and/or subspecies. Threat categories therefore reflect the overall conservation 
status of the species, which may for example be of Least Concern despite particular populations/sub-species being highly threatened. In some cases subspecies and/or populations are also assessed individually, but these results are not included in the statistics and analyses presented in this paper.

\section{Bibliography}

A list of important references used to compile the information for each species assessment was recorded for each species.

\subsection{Limitations of the Data}

Although we consider the current dataset to be the most comprehensive currently available for mammals, covering all known species, there are limitations. In particular, the following should be noted:

\section{Missing species and species coverage}

Since mid-1992 (when the second edition of Mammal Species of the World was compiled; 26), 373 new living mammal species were described-a rate of 24+ new descriptions per year (27) (this excludes species discoveries resulting from taxonomic changes). The rate of mammal descriptions remains high, with 61 species described in the years 2006 and 2007 alone. The overall number of species discoveries is much higher: Patterson (28) found that for every newly described species of Neotropical mammals (in the 1982 -1993 period), three others were rediscovered in Museum drawers and biochemical labs, ressurected from prior synonymy.

Although we have endeavored to trace all recently described species, it is possible one or two may have eluded our attention, especially if published in obscure media. In general, the cut-off date for including species in the present assessment was Dec $31^{\text {st }}, 2007$; however, a few species described in 2008 (Rhynchocyon udzungwensis [29], Miniopterus 
petersoni [30], Cacajao hosomi and C. ayresi [31]) are included. A single species currently in press (Mico sp. nov.) has also been included.

It is worth noting that the mammal faunas in some parts of the world remain poorly known, including, for example, the Andes, most of Central Africa and parts of West Africa, Angola, parts of South and Southeast Asia, and Melanesia. In addition, many species' names, especially in the tropics, actually represent complexes of several species that have not yet been resolved. For our purposes, and pending the availability of published information to the contrary, these are treated as single species, until resolution of their taxonomic status is published.

Domestic species (e.g. Dromedary Camelus dromedarius; Domestic Goat Capra hircus; Domestic Sheep Ovis aries) were excluded from this assessment.

\section{Incomplete ranges}

Because of the conservative approach taken in mapping species, the ranges for many are likely to be minimum estimates of the limits of species' distributions. A rule was followed allowing interpolation of occurrence between known localities if the ecological conditions seemed appropriate, but not permitting extrapolation beyond known localities. In other words, to the best of our knowledge, maps represent current known limits within historical native range (any introductions are coded accordingly, and are excluded for the purposes of analysis), with the obvious caveat that species occurrence is not homogeneous within the polygon. Some species are therefore almost certain to occur more widely than mapped. Because of this, some regions are recorded as having lower mammal diversity than may eventually prove to be the case. On the other hand, species' ranges were mapped as generalised polygons which often include areas of unsuitable habitat, and therefore species may not occur in all of the areas where they are mapped. 


\section{Threats}

The information on the relative importance of different threatening processes to mammal species is incomplete. We coded all threats that appear to have an important impact, but not their relative importance for each species.

\section{Data Deficient species}

A taxon is Data Deficient when there is inadequate information to make a direct, or indirect, assessment of its risk of extinction based on its distribution and/or population status. A taxon in this category may be well studied, and its biology well known, but appropriate data on abundance and/or distribution are lacking. Data Deficient is therefore not a category of threat. Listing of taxa in this category indicates that more information is required and acknowledges the possibility that future research will show that threatened classification is appropriate (5).

The percentage of species assessed as Data Deficient (15\%) is higher than previously indicated for mammals (7.8\%) (32). There are three likely explanations for this. The first has to do with the large number of recently described species for which it is difficult to discern the real taxonomic and distributional limits of the taxa being assessed. This is particularly the case for many of the recently described lemurs in Madagascar, where 42 were assessed as Data Deficient. The second explanation is due to a number of species formerly erroneously listed as Least Concern moving to the category Data Deficient, particularly in the New World. The third is simply due to lack of knowledge that permits a reliable assessment. Because many Data Deficient species are likely to have small distributions or populations, or both, they are intrinsically likely to be threatened. Consequently, in accordance with IUCN guidelines, species assessed as Data Deficient

should not be considered as "not threatened". With further survey work and the availablility of improved information, it is anticipated that many of these species, if indeed proven to be valid taxa, will be reassessed. This is a deliberate precautionary approach in accordance with the IUCN guidelines. 


\section{Analyzed data}

A subset of those data collected, both tabular and spatial, was used in the present analyses.

\subsection{Tabular data}

The analyzed data included tabular information for 5487 species. These correspond to all evaluated, excluding Homo sapiens.

- $\quad$ Taxonomy: allocation of each species to genus, family and order.

- $\quad$ Conservation status: each species was classified under one of the IUCN Red List Categories - Least Concern, Near Threatened, Vulnerable, Endangered, Critically Endangered (including Critically Endangered - Possibly Extinct), Extinct, Extinct in the Wild and Data Deficient.

- $\quad$ Population trends: current known or inferred trends of each species' overall population, described as increasing, decreasing, stable, or unknown.

- Threats: mechanisms in which species populations are negatively affected, including both those driven directly by human activities (e.g., habitat loss, pollution) and those that correspond to natural processes (which may be magnified by human activities; e.g., diseases). In these analyses we considered the following main threat types: habitat loss and degradation, harvesting, pollution, accidental mortality, diseases and invasives (20). Note that a species may be not threatened (sensu IUCN Red List, i.e. not categorized as Vulnerable, Endangered or Critically Endangered) and still be affected by a particular threat. Throughout, we consistently refer to the former as 'threatened species' and to the latter as 'species affected by threat X'. Also note that for a species to be listed as affected by a particular threat it has to be negatively affected (or potentially affected); 
for example, species codded as affected by 'harvesting' are not all of those for which harvested as been recorded, but those for which harvesting has a negative effect.

- Date of description: the date when a taxon was first recognized as unique (either as a species or as a subspecies). A species' date of description is often not equivalent to the date of discovery. The overall number of species recognized increases over time as a result of both new species descriptions and taxonomic changes elevating previously described taxa to the species level.

These data represent only a subset of the information collected for each species as part of the IUCN Red List assessments (see Section 1).

\subsection{Spatial data}

Distribution maps were available for 5395 species. This is a subset of those species for which tabular data were available, excluding 76 Extinct, two Extinct in the Wild, and 14 Data Deficient species and for which the range is insufficiently known.

Species were mapped as generalized polygons of plausible range, encompassing areas of known current presence. For the present analyses, only those polygons where the species was both reported as native (or possibly native, including reintroduced) and currently present (or possibly present) were included, thus excluding historical and introduced ranges.

As described above, species' range maps are coarse generalizations of their distributions, generally obtained as 'envelopes' including original records (point data) and through interpolation (using, for example, habitat information) from original records. They may include relatively extensive areas from which the species is absent (e.g., terrestrial habitats within a freshwater species' range) and are therefore likely to overestimate the species' true area of occupancy (33). Nonetheless, at the coarse scale of the present

analyses (spatial units $\sim 22,300 \mathrm{~km}^{2}$, see below) this bias is not expected to significantly affect the global spatial patterns found (33). 
For poorly known species, particularly those considered Data Deficient and known from only a few records, the mapped range may underestimate the true distribution.

Most species' ranges were either wholly in land (including freshwater and volant species) or in the sea, but seven species were mapped across both. These include, for example, the West African Manatee (Trichechus senegalensis) that occupies coastal marine, estuarine, and freshwater habitats in West Africa, using coastal areas as far as $75 \mathrm{~km}$ offshore (34) and rivers as far as $2000 \mathrm{~km}$ inland (35). For these 'cross-realm' species, their ranges were split into marine and land sections (using the coastline as the boundary) and analyzed separately (see below). Overall, 5282 species were maped as land mammals and 120 species were mapped as marine mamals, with seven species in common between both lists.

The separation between land and marine species was purely based on their mapped ranges, not on the habitats that they use. As a result, some that use marine habitats were mapped completely in land. These include freshwater and/or estuarine species that occupy a marine area that is too narrow to map, for example: Eurasian Otter (Lutra lutra), which in some parts of its range forages within a few hundred meters offshore (36); Water Rat (Hydromys chrysogaster), a mainly freshwater and brackish water species that also uses coastal mangroves (37). 


\section{Methods}

\subsection{Spatial units}

Data were analyzed using a geodesic discrete global grid system, defined on an icosahedron and projected to the sphere using the inverse Icosahedral Snyder Equal Area (ISEA) Projection (38). This corresponds to a hexagonal grid composed of individual units (cells) that retain their shape and area $\left(22,300 \mathrm{~km}^{2}\right)$ throughout the globe. These are more suitable for a range of ecological applications than the most commonly used rectangular grids (39). A row of cells near latitude $180^{\circ} \mathrm{E} / \mathrm{W}$ was excluded (Fig. S2) as these interfered with the spatial analyses. This creates an artificial narrow band of no data around all maps (Fig. 1, 2, 4).

The range of each species was converted to the hexagonal grid for analysis purposes, with land and marine cells (and their species) analyzed separately. Coastal cells were clipped to the coastline into land and marine sections. The ranges of 'cross-realm' species were also clipped to the coastline into land and marine sections, and analyzed accordingly with land and marine cells.

The maps created in each analysis (Fig. 1, 2, 4) have patterns for marine species mapped on a blue scale, and patterns for land species mapped on a brown scale. Different numerical scales are used for land and marine, as the numbers of species differ by more than an order of magnitude. 
A

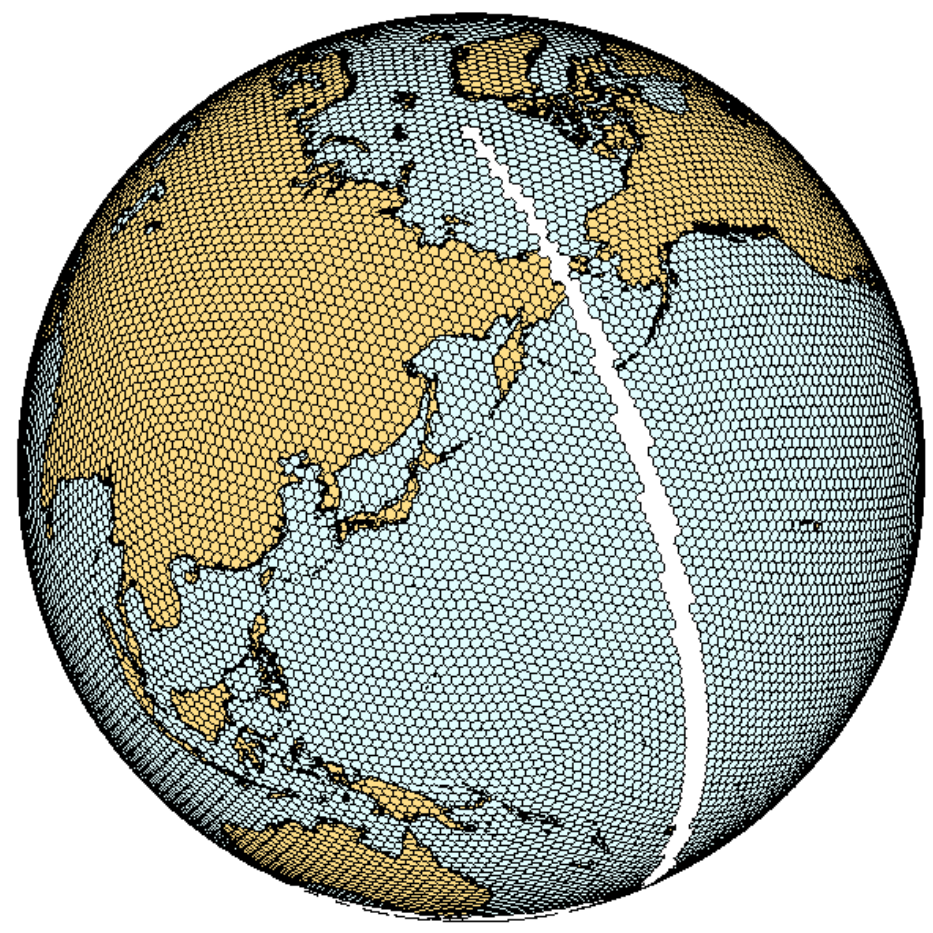

B

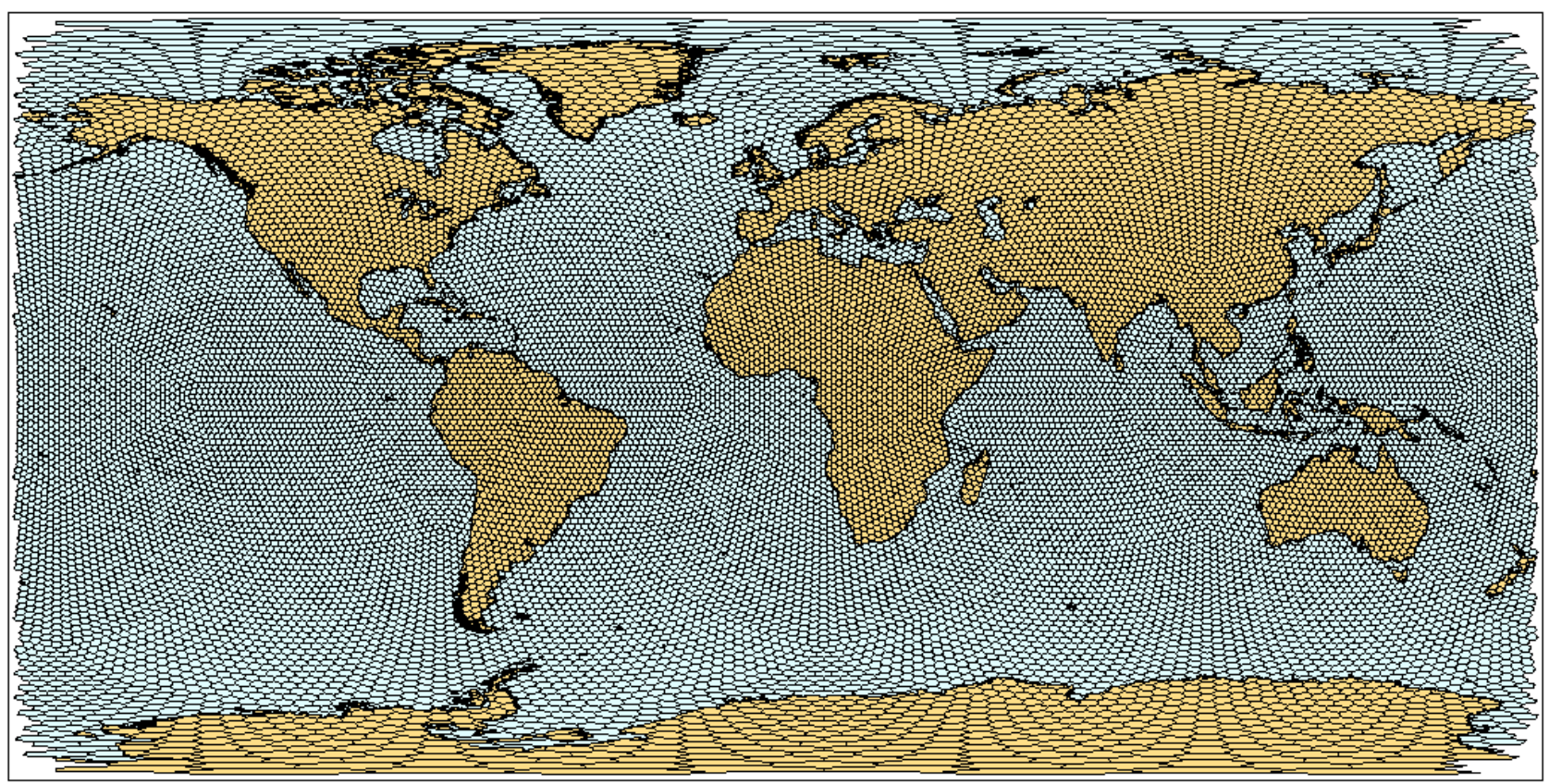

Fig. S2. Hexagonal grid used in the spatial analysis: A) viewed on a globe; B) on a cylindrical projection. Cells near $180^{\circ} \mathrm{E} / \mathrm{W}$ were excluded. 


\subsection{Species richness}

Patterns of species richness (Fig. 1A) were mapped by counting the number of species in each cell (or cell section, for species with a coastal distribution).

Information on the percentage of species in tropical and subtropical moist broadleaf forests was obtained using the biome coverage by Olson and colleagues (40).

\subsection{Phylogenetic diversity}

We created a phylogenetic tree encompassing all analyzed species based on a recently published mammalian super tree (41). The original phylogeny comprised 4510 species. Of these, 4506 were matched to a species in the current assessment (3909 matched directly; 597 matched to a synonym); the unmatched four were either extinct prior to 1500 , or domestic. One hundred and fifty-five species were deleted from the original tree: 138 corresponding to taxa no longer recognized as separate species (lumped to another species already on the tree); four for which no match was found; 12 that are Extinct or Extinct in the Wild; and Homo sapiens. Deleting this set of species from the tree was done by removing all unique branches associated with it.

The resulting sub-tree had 4355 species. This was expanded to include all extant species assessed by adding 1054 extra species. Those were added to the tree using information on their taxonomy to infer their relative phylogenetic position. The following rules were adopted when adding a new species to the tree:

- $\quad$ For species that were added to existing polytypic genera (946 species), each was added as a split at the basal branch for the corresponding genera (i.e. the last branch common to all species in a given genus).

- For species that were added to existing monotypic genera (81 species), the monotypic genus was split into two species, with the position of the split given by the average split position of polytypic genera in the same family. In families composed of 
monotypic genera only, the position was given by the average split position of polytypic genera in the same order. In one case where the order had only monotypic genera, the position was given by the average split position of polytypic genera across all mammals.

- $\quad$ For species that corresponded to new genera (26 species), a new branch was added at the basal branch for the corresponding family.

- For one species that corresponded to a new family, a new branch was added at the basal branch for the corresponding order.

The final phylogenetic tree comprised 5409 species, which includes all 5395 species for which distribution maps were available.

The phylogenetic diversity of a given site is a measure of species diversity that accounts for the phylogenetic relationship between species $(42,43)$. It is calculated as the sum total of the branch lengths for the sub-tree representing all species at the site (Fig. S3A; 4244). Given two sites with the same number of species, the phylogenetic diversity is higher when species are less related (Fig. S3B) than when they are clustered in the taxonomic tree (Fig. S3C). The phylogenetic diversity of a site is therefore not a measure of the phylogenetic uniqueness of the site's fauna, but a measure of the overall evolutionary history encompassed by all species at the site.

The phylogenetic diversity of each cell was mapped for land and marine species (Fig. 1B). 

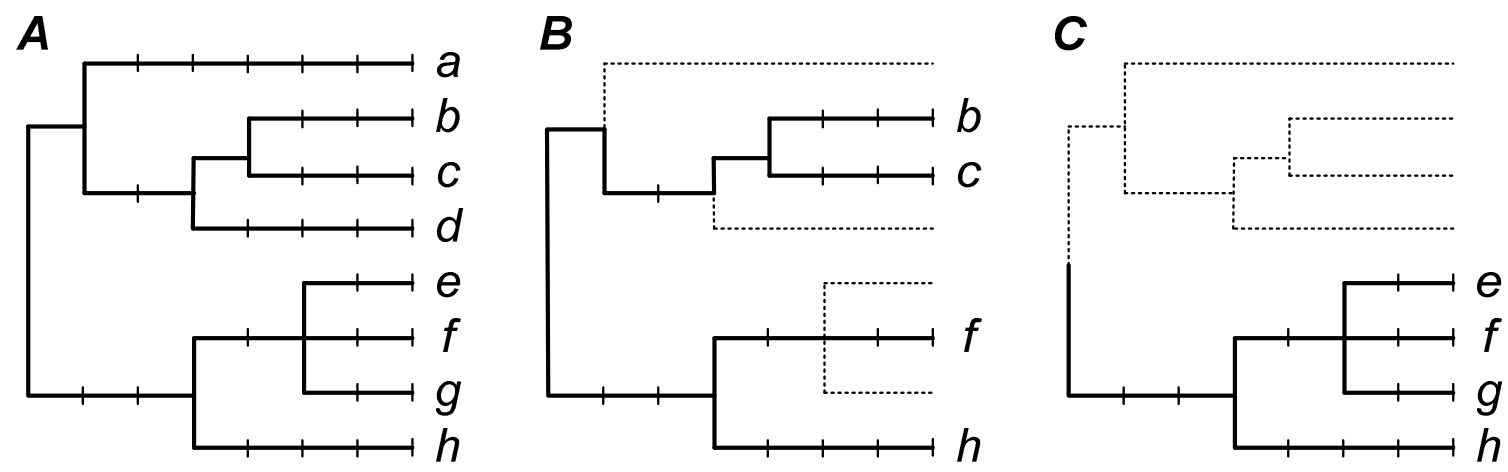

Fig. S3. Illustration of the method for calculating the phylogenetic diversity of a set of species. A) Hypothetical phylogenetic tree with eight taxa, $a$ to $h$. The length of each branch is given by the number of intervals. The phylogenetic diversity of the tree is the sum of the length of the branches; for all species, phylogenetic diversity $=35$. B) Subtree for taxa $b, c, f$, and $h$, with phylogenetic diversity = 21. C) Sub-tree for taxa $e, f, g$, and $h$, with phylogenetic diversity $=15$. Adapted from (44).

\subsection{Restricted-range species}

Restricted-range species were defined as those $25 \%$ of species with the smallest range sizes (45-47). Range sizes were calculated in GIS, directly from the species' polygons on an equal-area projection. Restricted-range species were defined separately for land $(n=1321)$ and for marine $(n=30)$ species. For cross-realm species, the value used was that of the entire range (not just the land or marine sections). Richness in restricted-range species was mapped to identify areas that are global centers of endemism for land and marine species (Fig. 1C).

\subsection{Median range size}

The spatial pattern of variation in species' range sizes was investigated by calculating, for each cell, the median area of the range of all species present (Fig. 1D). A similar approach was applied to birds in previous studies (48-49). For cross-realm species, the range size was that of the entire range (not just the land or marine sections). 


\subsection{Threat levels}

Threat levels (percentage of threatened species within a group) cannot be determined exactly given that for Data Deficient species the threat status could not be determined. Threat levels are therefore presented as an estimated mid-point, and a range between a lower bound and an upper bound. These are defined as:

- $\quad$ Mid-point: percentage of threatened species amongst those for which threat status could be determined (number of threatened species divided by the number of non-Data Deficient species). This corresponds to the assumption that Data Deficient species have the same fraction of threatened species as the other species.

- $\quad$ Lower bound: percentage of threatened species amongst all species assessed (number of threatened species divided by the total number of species assessed). This corresponds to the assumption that none of the Data Deficient species are threatened.

- $\quad$ Upper bound: percentage of threatened or Data Deficient species amongst those assessed (number of threatened or Data Deficient species divided by the total number of species assessed). This corresponds to the assumption that all of the Data Deficient species are threatened.

Threat levels obtained in the 2008 Red List Assessment are not directly comparable with those from 1996 (4), because the categories and criteria employed to allocate species to threat classes have changed (50), and because more than 850 new species have since been described or revalidated.

The number of threatened species in each cell was mapped (Fig. 2A) by counting the number of species in IUCN Categories Vulnerable, Endangered or Critically Endangered. The number of species affected by habitat loss and degradation (Fig. 2B), harvesting (Fig. 2C), accidental mortality (Fig. 2D) and pollution (Fig. 2E) was obtained by counting those species in each cell that are affected by such a threat. As described above, these species are not necessarily threatened, and a species may be affected by more than one 
threat. These four threat categories were chosen to be mapped as they include the two main threats for land species (habitat loss, harvesting) and the two main threats for marine species (accidental mortality, pollution). Note that harvesting does not include direct persecution (e.g. for pest control) or accidental mortality (e.g. fisheries by-catch), which are coded separately. Pollution includes noise pollution and global warming (20).

Given that no information has been compiled on which threats are most important for each species, we use the number of species affected by each threat as a measure of the relative importance of different threats.

One-tailed binomial tests were used to investigate which mammalian families have higher or lower than expected percentages of threatened or extinct species (Figure 3). Three families (Neobalaenidae, Notoryctidae and Odobenidae) are not represented in Figure 3 because all of their species are Data Deficient. Care is needed in interpreting these results. That a given family has a significantly lower proportion of threatened or extinct species than the average across mammals does not necessarily mean that it is at low risk of threat in absolute terms. Species extinctions are relatively rare events in geological time (51), and therefore most taxa are highly threatened in relation to what would be expected in the absence of human activities.

\subsection{Knowledge}

The number of species that have been described since 1992 was obtained as the difference between the date of species included in the current assessment and those recognized in the second edition of Mammal Species of the World (26) (with a cut off date of July 1992 for the inclusion of species). The number of newly described species in the 1992-2008 period has been obtained from the original year of description. The ranges of newly described species were mapped to illustrate areas where new knowledge of mammalian diversity has recently emerged (Fig. 4A). The number of Data Deficient species per cell has been mapped to illustrate areas in need of future research (Fig. 4B). 


\section{Additional results}

\subsection{Relationship between latitude and species richnees}

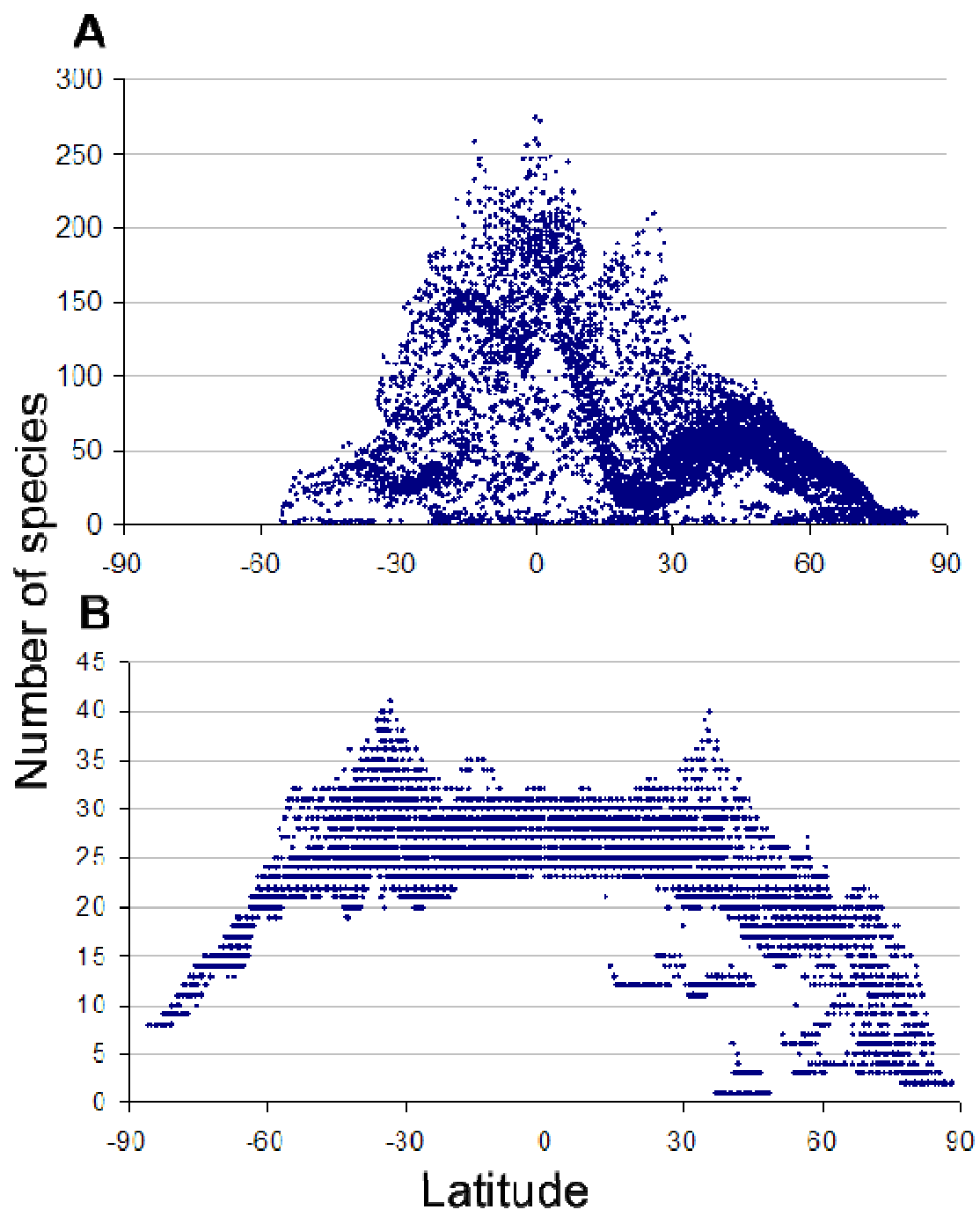

Fig. S4. Relationship between latitude and species richness per cell for: A) land species; B) marine species. Northern latitudes positive, southern latitudes negative. 


\subsection{Relationship between species richness and phylogenetic diversity}

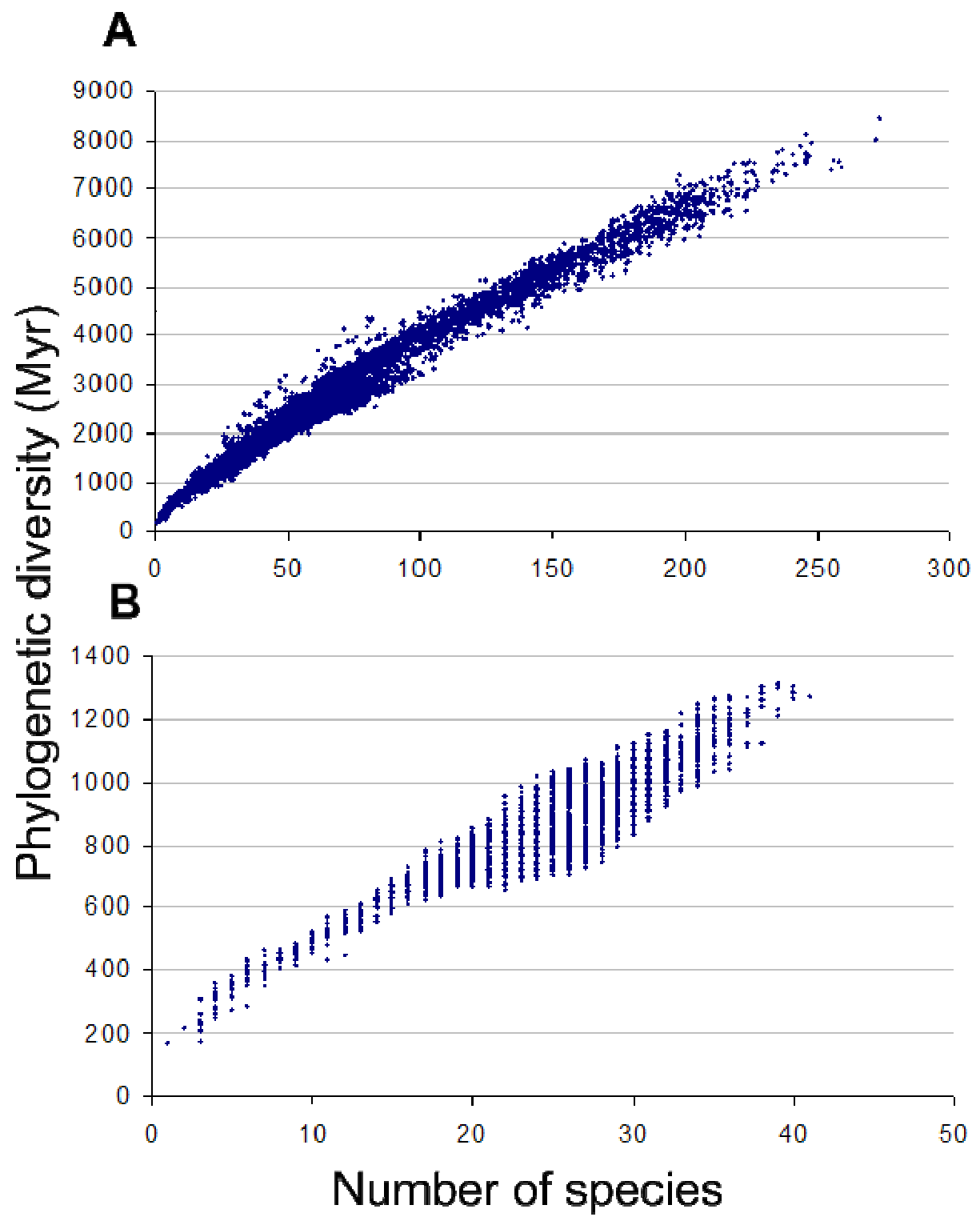

Fig. S5. Relationship between species richness and phylogenetic diversity across: A) land species $\left.\left(r^{2}=0.98\right) ; B\right)$ marine species $\left(r^{2}=0.73\right)$. 


\subsection{Range size distribution}

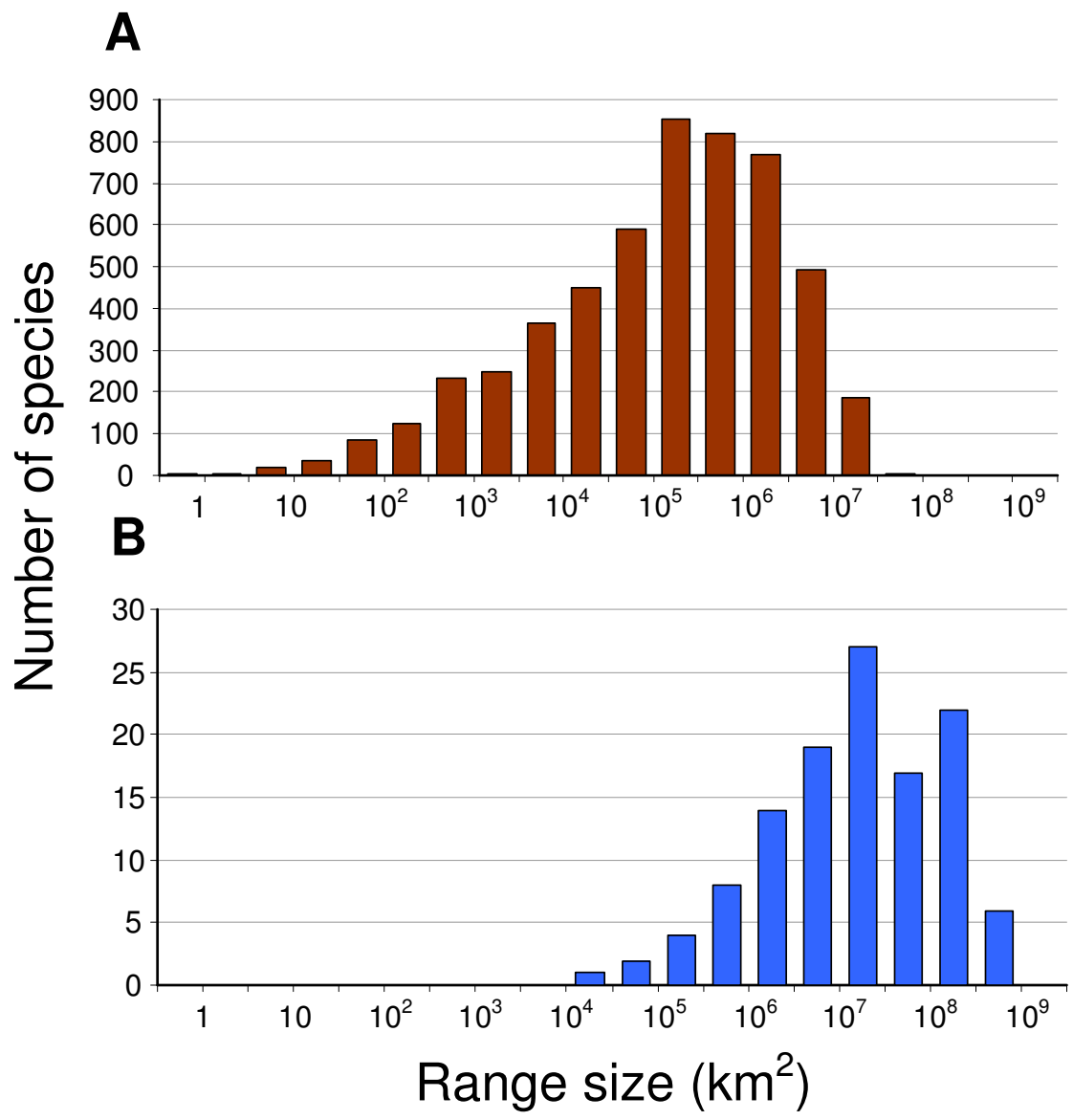

Fig. S6. Frequency distribution of range sizes for (A) land mammals ( $n=5282$; first quartile $\sim 17,700 \mathrm{~km}^{2}$; median $\sim 193.6 \mathrm{~km}^{2}$; three species range smaller than $1 \mathrm{~km}^{2}$ are lumped with the first class) and (B) marine mammals ( $n=120$; first quartile $~ 3.8$ million $\mathrm{km}^{2}$; median $\sim 14.5$ million $\mathrm{km}^{2}$ ). 


\subsection{Relationship between range size and latitude}

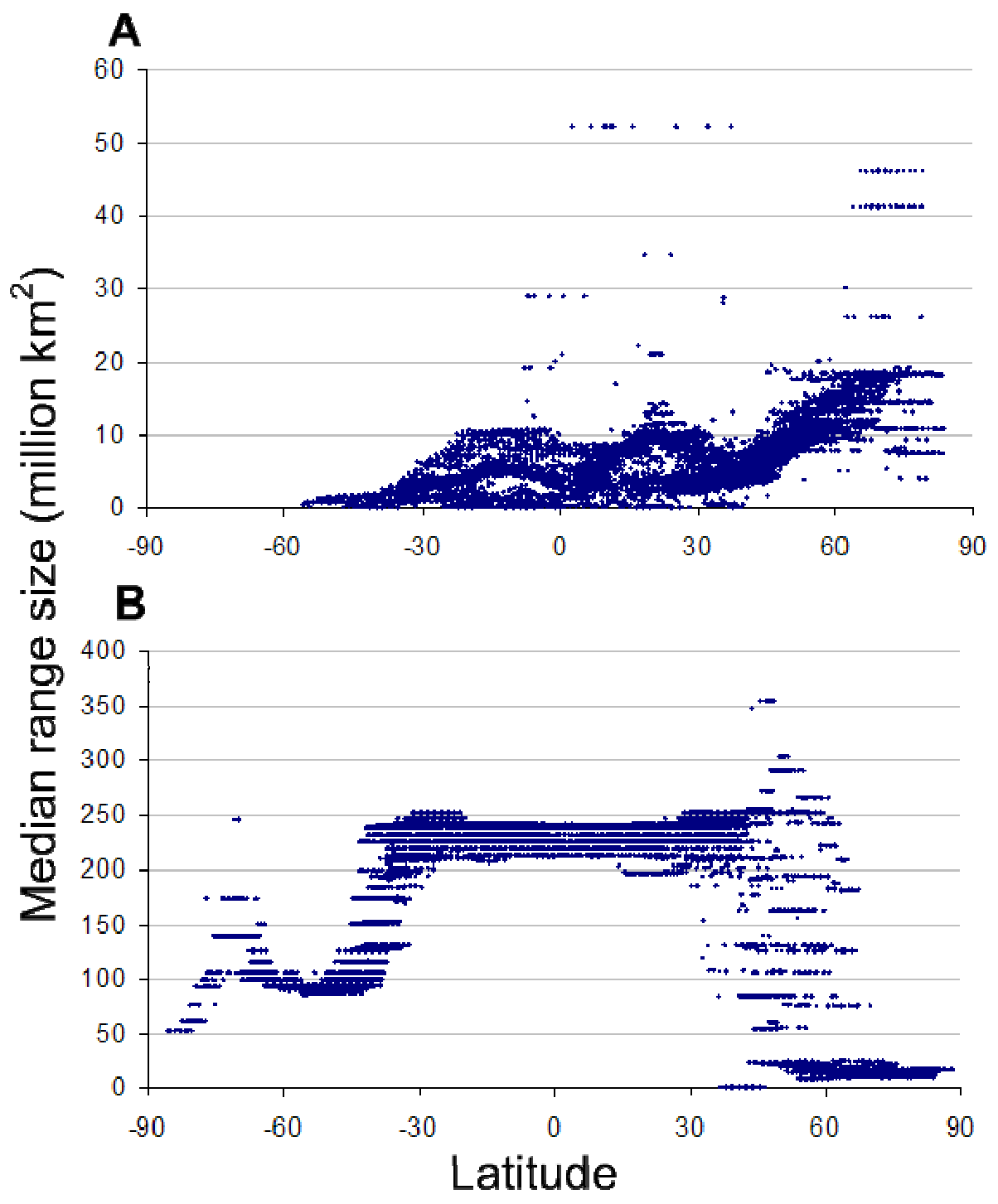

Fig. S7. Variation in median range size of species in each cell according to cell latitude, for: A) land mammals and B) marine mammals. Northern latitudes positive, southern latitudes negative. 


\subsection{Threat levels across families}

Table S1: Number of species in each IUCN Red List Category (EX - Extinct; EW Extinct in the Wild; CR - Critically Endangered; VU - Vulnerable; EN - Endangered; LC - Least Concern; DD - Data Deficient) for all mammals and for those in each order (grey rows) and each family. For each order or family, we present the significance level from a binomial test comparing the corresponding percentage of threatened or extinct species (amongst non-DD species) with the overall percentage across all species (26\%;

Figure 3).

\begin{tabular}{|c|c|c|c|c|c|c|c|c|c|c|c|}
\hline FAMILY & $\mathbf{E X}$ & EW & 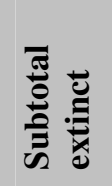 & $\mathbf{C R}$ & EN & $\mathbf{V U}$ & 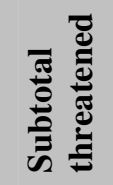 & NT & $\mathbf{L C}$ & DD & 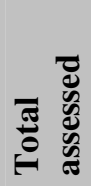 \\
\hline ALL MAMMALS & 79 & 2 & 81 & 188 & 448 & 505 & 1141 & 323 & 3109 & 835 & 5489 \\
\hline \multicolumn{12}{|l|}{ MONOTREMATA (ns) } \\
\hline Ornithorhynchidae (ns) & 0 & 0 & 0 & 0 & 0 & 0 & 0 & 0 & 1 & 0 & 1 \\
\hline Tachyglossidae (ns) & 0 & 0 & 0 & 3 & 0 & 0 & 3 & 0 & 1 & 0 & 4 \\
\hline Total Monotremata & $\mathbf{0}$ & $\mathbf{0}$ & $\mathbf{0}$ & 3 & $\mathbf{0}$ & $\mathbf{0}$ & 3 & $\mathbf{0}$ & 2 & $\mathbf{0}$ & 5 \\
\hline \multicolumn{12}{|c|}{ DIDELPHIMORPHIA ${ }^{\& \&}$} \\
\hline Didelphidae ${ }^{\& \&}$ & 1 & 0 & 1 & 1 & 0 & 7 & 8 & 2 & 67 & 17 & 95 \\
\hline \multicolumn{12}{|c|}{ PAUCITUBERCULATA (ns) } \\
\hline Caenolestidae (ns) & 0 & 0 & 0 & 0 & 0 & 2 & 2 & 2 & 2 & 0 & 6 \\
\hline \multicolumn{12}{|l|}{ MICROBIOTHERIA (ns) } \\
\hline Microbiotheriidae (ns) & 0 & 0 & 0 & 0 & 0 & 0 & 0 & 1 & 0 & 0 & 1 \\
\hline \multicolumn{12}{|c|}{ NOTORYCTEMORPHIA $^{2}$} \\
\hline Notoryctidae $^{2}$ & 0 & 0 & 0 & 0 & 0 & 0 & 0 & 0 & 0 & 2 & 2 \\
\hline \multicolumn{12}{|c|}{ DASYUROMORPHIA（ns) } \\
\hline Dasyuridae $^{\&}$ & 0 & 0 & 0 & 1 & 5 & 5 & 11 & 10 & 47 & 4 & 72 \\
\hline Myrmecobiidae (ns) & 0 & 0 & 0 & 0 & 1 & 0 & 1 & 0 & 0 & 0 & 1 \\
\hline Thylacinidae (ns) & 1 & 0 & 1 & 0 & 0 & 0 & 0 & 0 & 0 & 0 & 1 \\
\hline Total Dasyurmorphia & 1 & $\mathbf{0}$ & 1 & 1 & 6 & 5 & 12 & 10 & 47 & 4 & 74 \\
\hline \multicolumn{12}{|c|}{ PERAMELEMORPHIA * } \\
\hline Chaeropodidae (ns) & 1 & 0 & 1 & 0 & 0 & 0 & 0 & 0 & 0 & 0 & 1 \\
\hline Peramelidae (ns) & 1 & 0 & 1 & 0 & 4 & 1 & 5 & 1 & 9 & 3 & 19 \\
\hline Thylacomyidae (ns) & 1 & 0 & 1 & 0 & 0 & 1 & 1 & 0 & 0 & 0 & 2 \\
\hline Total Peramelemorphia & 3 & $\mathbf{0}$ & 3 & $\mathbf{0}$ & 4 & 2 & 6 & 1 & 9 & 3 & 22 \\
\hline
\end{tabular}




\begin{tabular}{|c|c|c|c|c|c|c|c|c|c|c|c|}
\hline FAMILY & EX & EW & 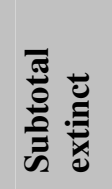 & $\mathbf{C R}$ & EN & $\mathbf{V U}$ & 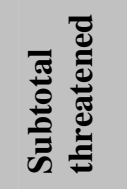 & NT & $\mathbf{L C}$ & DD & 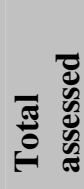 \\
\hline \multicolumn{12}{|l|}{ DIPROTODONTIA ** } \\
\hline Acrobatidae (ns) & 0 & 0 & 0 & 0 & 0 & 0 & 0 & 0 & 2 & 0 & 2 \\
\hline Burramyidae (ns) & 0 & 0 & 0 & 1 & 0 & 0 & 1 & 0 & 4 & 0 & 5 \\
\hline Hypsiprymnodontidae(ns) & 0 & 0 & 0 & 0 & 0 & 0 & 0 & 0 & 1 & 0 & 1 \\
\hline Macropodidae* & 4 & 0 & 4 & 5 & 8 & 9 & 22 & 10 & 30 & 1 & 67 \\
\hline Petauridae (ns) & 0 & 0 & 0 & 1 & 3 & 0 & 4 & 0 & 7 & 0 & 11 \\
\hline Phalangeridae (ns) & 0 & 0 & 0 & 4 & 2 & 4 & 10 & 1 & 14 & 1 & 26 \\
\hline Phascolarctidae (ns) & 0 & 0 & 0 & 0 & 0 & 0 & 0 & 0 & 1 & 0 & 1 \\
\hline Potoroidae** & 3 & 0 & 3 & 2 & 2 & 0 & 4 & 2 & 2 & 0 & 11 \\
\hline Pseudocheiridae (ns) & 0 & 0 & 0 & 0 & 0 & 3 & 3 & 3 & 12 & 0 & 18 \\
\hline Tarsipedidae (ns) & 0 & 0 & 0 & 0 & 0 & 0 & 0 & 0 & 1 & 0 & 1 \\
\hline Vombatidae (ns) & 0 & 0 & 0 & 1 & 0 & 0 & 1 & 0 & 2 & 0 & 3 \\
\hline Total Diprotodontia & 7 & $\mathbf{0}$ & 7 & 14 & 15 & 16 & 45 & 16 & 76 & 2 & 146 \\
\hline \multicolumn{12}{|l|}{ TUBULIDENTATA (ns) } \\
\hline Orycteropodidae (ns) & 0 & 0 & 0 & 0 & 0 & 0 & 0 & $\mathbf{0}$ & 1 & 0 & 1 \\
\hline \multicolumn{12}{|l|}{ SIRENIA $* *$} \\
\hline Dugongidae (ns) & 1 & 0 & 1 & 0 & 0 & 1 & 1 & 0 & 0 & 0 & 2 \\
\hline Trichechidae* & 0 & 0 & 0 & 0 & 0 & 3 & 3 & 0 & 0 & 0 & 3 \\
\hline Total Sirenia & 1 & $\mathbf{0}$ & 1 & $\mathbf{0}$ & $\mathbf{0}$ & 4 & 4 & $\mathbf{0}$ & $\mathbf{0}$ & $\mathbf{0}$ & 5 \\
\hline \multicolumn{12}{|l|}{ AFROSORICIDA（ns) } \\
\hline Chrysochloridae** & 0 & 0 & 0 & 1 & 4 & 5 & 10 & 2 & 6 & 3 & 21 \\
\hline Tenrecidae (ns) & 0 & 0 & 0 & 0 & 3 & 4 & 7 & 1 & 24 & 1 & 33 \\
\hline Total Afrosoricida & $\mathbf{0}$ & $\mathbf{0}$ & $\mathbf{0}$ & 1 & 7 & 9 & 17 & 3 & 30 & 4 & 54 \\
\hline \multicolumn{12}{|c|}{ MACROSCELIDEA (ns) } \\
\hline Macroscelididae (ns) & 0 & 0 & 0 & 0 & 1 & 2 & 3 & 1 & 9 & 3 & 16 \\
\hline \multicolumn{12}{|l|}{ HYRACOIDEA（ns) } \\
\hline Procaviidae (ns) & 0 & 0 & 0 & 0 & 0 & 0 & 0 & 0 & 5 & 0 & 5 \\
\hline \multicolumn{12}{|l|}{ PROBOSCIDEA (ns) } \\
\hline Elephantidae (ns) & 0 & 0 & 0 & 0 & 1 & 0 & 1 & 1 & 0 & 0 & 2 \\
\hline \multicolumn{12}{|l|}{ CINGULATA (ns) } \\
\hline Dasypodidae (ns) & 0 & 0 & 0 & 0 & 0 & 4 & 4 & 5 & 9 & 3 & 21 \\
\hline
\end{tabular}




\begin{tabular}{|c|c|c|c|c|c|c|c|c|c|c|c|}
\hline FAMILY & EX & EW & 䒿 & CR & EN & $\mathbf{V U}$ & 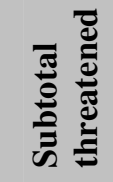 & NT & LC & DD & 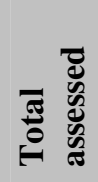 \\
\hline \multicolumn{12}{|l|}{ PILOSA (ns) } \\
\hline Bradypodidae (ns) & 0 & 0 & 0 & 1 & 1 & 0 & 2 & 0 & 2 & 0 & 4 \\
\hline Cyclopedidae (ns) & 0 & 0 & 0 & 0 & 0 & 0 & 0 & 0 & 1 & 0 & 1 \\
\hline Megalonychidae (ns) & 0 & 0 & 0 & 0 & 0 & 0 & 0 & 0 & 2 & 0 & 2 \\
\hline Myrmecophagidae (ns) & 0 & 0 & 0 & 0 & 0 & 0 & 0 & 1 & 2 & 0 & 3 \\
\hline Total Pilosa & $\mathbf{0}$ & $\mathbf{0}$ & $\mathbf{0}$ & 1 & 1 & $\mathbf{0}$ & 2 & 1 & 7 & $\mathbf{0}$ & 10 \\
\hline \multicolumn{12}{|l|}{ SCANDENTIA (ns) } \\
\hline Ptilocercidae (ns) & 0 & 0 & 0 & 0 & 0 & 0 & 0 & 0 & 1 & 0 & 1 \\
\hline Tupaiidae (ns) & 0 & 0 & 0 & 0 & 2 & 0 & 2 & 0 & 14 & 3 & 19 \\
\hline Total Scandentia & $\mathbf{0}$ & $\mathbf{0}$ & $\mathbf{0}$ & $\mathbf{0}$ & 2 & $\mathbf{0}$ & 2 & $\mathbf{0}$ & 15 & 3 & 20 \\
\hline \multicolumn{12}{|l|}{ DERMOPTERA (ns) } \\
\hline Cynocephalidae (ns) & 0 & 0 & 0 & 0 & 0 & 0 & 0 & 0 & 2 & 0 & 2 \\
\hline \multicolumn{12}{|l|}{ PRIMATES $* * *$} \\
\hline Aotidae (ns) & 0 & 0 & 0 & 0 & 0 & 4 & 4 & 0 & 5 & 2 & 11 \\
\hline Atelidae*** & 0 & 0 & 0 & 5 & 8 & 5 & 18 & 0 & 10 & 0 & 28 \\
\hline Callitrichidae (ns) & 0 & 0 & 0 & 2 & 6 & 6 & 14 & 2 & 20 & 6 & 42 \\
\hline Cebidae (ns) & 0 & 0 & 0 & 3 & 1 & 2 & 6 & 2 & 9 & 0 & 17 \\
\hline Cercopithecidae $* * *$ & 0 & 0 & 0 & 12 & 29 & 31 & 72 & 11 & 37 & 2 & 122 \\
\hline Cheirogaleidae (ns) & 0 & 0 & 0 & 0 & 4 & 2 & 6 & 1 & 7 & 15 & 29 \\
\hline Daubentoniidae (ns) & 0 & 0 & 0 & 0 & 0 & 0 & 0 & 1 & 0 & 0 & 1 \\
\hline Galagidae $^{\&}$ & 0 & 0 & 0 & 1 & 0 & 0 & 1 & 1 & 15 & 1 & 18 \\
\hline Hominidae $* * *$ & 0 & 0 & 0 & 2 & 4 & 0 & 6 & 0 & 0 & 0 & 6 \\
\hline Hylobatidae*** & 0 & 0 & 0 & 4 & 11 & 1 & 16 & 0 & 0 & 0 & 16 \\
\hline Indriidae $* * *$ & 0 & 0 & 0 & 2 & 8 & 2 & 12 & 0 & 1 & 5 & 18 \\
\hline Lemuridae*** & 0 & 0 & 0 & 3 & 4 & 9 & 16 & 3 & 0 & 1 & 20 \\
\hline Lepilemuridae* & 0 & 0 & 0 & 1 & 1 & 1 & 3 & 0 & 0 & 21 & 24 \\
\hline Lorisidae* & 0 & 0 & 0 & 0 & 2 & 4 & 6 & 0 & 4 & 0 & 10 \\
\hline Palaeopropithecidae (ns) & 1 & 0 & 1 & 0 & 0 & 0 & 0 & 0 & 0 & 0 & 1 \\
\hline Pitheciidae* & 1 & 0 & 1 & 2 & 6 & 8 & 16 & 1 & 24 & 1 & 43 \\
\hline Tarsiidae** & 0 & 0 & 0 & 0 & 2 & 3 & 5 & 1 & 0 & 2 & 8 \\
\hline Total Primates & 2 & $\mathbf{0}$ & 2 & 37 & 86 & 78 & 201 & 23 & 132 & 56 & 414 \\
\hline
\end{tabular}




\begin{tabular}{|c|c|c|c|c|c|c|c|c|c|c|c|}
\hline FAMILY & EX & EW & 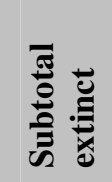 & CR & EN & VU & 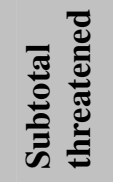 & NT & $\mathbf{L C}$ & DD & 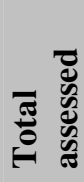 \\
\hline \multicolumn{12}{|l|}{ RODENTIA $^{\& \& \&}$} \\
\hline Abrocomidae (ns) & 1 & 0 & 1 & 1 & 0 & 0 & 1 & 0 & 2 & 6 & 10 \\
\hline Anomaluridae (ns) & 0 & 0 & 0 & 0 & 0 & 0 & 0 & 0 & 6 & 1 & 7 \\
\hline Aplodontiidae (ns) & 0 & 0 & 0 & 0 & 0 & 0 & 0 & 0 & 1 & 0 & 1 \\
\hline Bathyergidae (ns) & 0 & 0 & 0 & 0 & 0 & 1 & 1 & 1 & 12 & 1 & 15 \\
\hline Calomyscidae (ns) & 0 & 0 & 0 & 0 & 0 & 0 & 0 & 0 & 6 & 2 & 8 \\
\hline Capromyidae*** & 6 & 0 & 6 & 4 & 4 & 3 & 11 & 1 & 1 & 0 & 19 \\
\hline Castoridae (ns) & 0 & 0 & 0 & 0 & 0 & 0 & 0 & 0 & 2 & 0 & 2 \\
\hline Caviidae (ns) & 0 & 0 & 0 & 1 & 0 & 0 & 1 & 2 & 12 & 3 & 18 \\
\hline Chinchillidae (ns) & 1 & 0 & 1 & 2 & 0 & 0 & 2 & 0 & 3 & 1 & 7 \\
\hline Cricetidae ${ }^{\& \& \&}$ & 15 & 0 & 15 & 21 & 31 & 44 & 96 & 34 & 468 & 85 & 698 \\
\hline Ctenodactylidae (ns) & 0 & 0 & 0 & 0 & 0 & 0 & 0 & 0 & 3 & 2 & 5 \\
\hline Ctenomyidae* & 0 & 0 & 0 & 3 & 6 & 6 & 15 & 5 & 16 & 24 & 60 \\
\hline Cuniculidae (ns) & 0 & 0 & 0 & 0 & 0 & 0 & 0 & 1 & 1 & 0 & 2 \\
\hline Dasyproctidae (ns) & 0 & 0 & 0 & 1 & 1 & 1 & 3 & 1 & 6 & 3 & 13 \\
\hline Diatomyidae (ns) & 0 & 0 & 0 & 0 & 1 & 0 & 1 & 0 & 0 & 0 & 1 \\
\hline Dinomyidae (ns) & 0 & 0 & 0 & 0 & 0 & 1 & 1 & 0 & 0 & 0 & 1 \\
\hline Dipodidae $e^{\& \&}$ & 0 & 0 & 0 & 0 & 2 & 2 & 4 & 4 & 34 & 8 & 50 \\
\hline Echimyidae (ns) & 4 & 0 & 4 & 2 & 7 & 4 & 13 & 0 & 47 & 25 & 89 \\
\hline Erethizontidae (ns) & 0 & 0 & 0 & 0 & 0 & 1 & 1 & 0 & 11 & 6 & 18 \\
\hline Geomyidae $^{\&}$ & 0 & 0 & 0 & 3 & 1 & 0 & 4 & 1 & 33 & 1 & 39 \\
\hline Gliridae (ns) & 0 & 0 & 0 & 0 & 0 & 2 & 2 & 1 & 15 & 10 & 28 \\
\hline Heteromyidae (ns) & 0 & 0 & 0 & 3 & 6 & 5 & 14 & 1 & 46 & 1 & 62 \\
\hline Hystricidae (ns) & 0 & 0 & 0 & 0 & 0 & 1 & 1 & 0 & 10 & 0 & 11 \\
\hline Muridae (ns) & 10 & 0 & 10 & 17 & 62 & 55 & 134 & 24 & 409 & 134 & 711 \\
\hline Myocastoridae (ns) & 0 & 0 & 0 & 0 & 0 & 0 & 0 & 0 & 1 & 0 & 1 \\
\hline Nesomyidae (ns) & 0 & 0 & 0 & 1 & 6 & 3 & 10 & 0 & 40 & 9 & 59 \\
\hline Octodontidae (ns) & 0 & 0 & 0 & 3 & 0 & 2 & 5 & 1 & 5 & 2 & 13 \\
\hline Pedetidae (ns) & 0 & 0 & 0 & 0 & 0 & 0 & 0 & 0 & 2 & 0 & 2 \\
\hline Petromuridae (ns) & 0 & 0 & 0 & 0 & 0 & 0 & 0 & 0 & 1 & 0 & 1 \\
\hline Platacanthomyidae (ns) & 0 & 0 & 0 & 0 & 0 & 1 & 1 & 0 & 1 & 0 & 2 \\
\hline Sciuridae $e^{\text {\&\&\& }}$ & 0 & 0 & 0 & 2 & 15 & 16 & 33 & 24 & 181 & 41 & 279 \\
\hline
\end{tabular}




\begin{tabular}{|c|c|c|c|c|c|c|c|c|c|c|c|}
\hline FAMILY & EX & EW & 离 & $\mathbf{C R}$ & EN & VU & 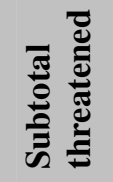 & NT & $\mathbf{L C}$ & DD & 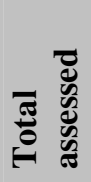 \\
\hline Spalacidae (ns) & 0 & 0 & 0 & 0 & 2 & 2 & 4 & 2 & 12 & 3 & 21 \\
\hline Thryonomyidae (ns) & 0 & 0 & 0 & 0 & 0 & 0 & 0 & 0 & 2 & 0 & 2 \\
\hline Total Rodentia & 37 & $\mathbf{0}$ & 37 & 64 & 144 & 150 & 358 & 103 & 1389 & 368 & 2255 \\
\hline \multicolumn{12}{|l|}{ LAGOMORPHA (ns) } \\
\hline Leporidae (ns) & 0 & 0 & 0 & 1 & 7 & 5 & 13 & 6 & 38 & 5 & 62 \\
\hline Ochotonidae (ns) & 0 & 0 & 0 & 1 & 3 & 0 & 4 & 0 & 23 & 3 & 30 \\
\hline Prolagidae (ns) & 1 & 0 & 1 & 0 & 0 & 0 & 0 & 0 & 0 & 0 & 1 \\
\hline Total Lagomorpha & 1 & $\mathbf{0}$ & 1 & 2 & 10 & 5 & 17 & 6 & 61 & 8 & 93 \\
\hline \multicolumn{12}{|c|}{ EULIPOTYPHLA (ns) } \\
\hline Erinaceidae (ns) & 0 & 0 & 0 & 0 & 2 & 1 & 3 & 0 & 20 & 1 & 24 \\
\hline Nesophontidae*** & 6 & 0 & 6 & 0 & 0 & 0 & 0 & 0 & 0 & 0 & 6 \\
\hline Solenodontidae* & 1 & 0 & 1 & 0 & 2 & 0 & 2 & 0 & 0 & 0 & 3 \\
\hline Soricidae (ns) & 0 & 0 & 0 & 12 & 36 & 28 & 76 & 12 & 217 & 71 & 376 \\
\hline Talpidae ${ }^{\& \&}$ & 0 & 0 & 0 & 0 & 1 & 2 & 3 & 1 & 32 & 5 & 41 \\
\hline Total Eulipotyphla & 7 & $\mathbf{0}$ & 7 & 12 & 41 & 31 & 84 & 13 & 269 & 77 & 450 \\
\hline \multicolumn{12}{|l|}{ CHIROPTERA ${ }^{\& \& \&}$} \\
\hline Craseonycteridae (ns) & 0 & 0 & 0 & 0 & 0 & 1 & 1 & 0 & 0 & 0 & 1 \\
\hline Emballonuridae ${ }^{\&}$ & 0 & 0 & 0 & 1 & 2 & 2 & 5 & 1 & 38 & 8 & 52 \\
\hline Furipteridae (ns) & 0 & 0 & 0 & 0 & 1 & 0 & 1 & 0 & 1 & 0 & 2 \\
\hline Hipposideridae (ns) & 0 & 0 & 0 & 1 & 4 & 10 & 15 & 7 & 44 & 18 & 84 \\
\hline Megadermatidae (ns) & 0 & 0 & 0 & 0 & 0 & 1 & 1 & 0 & 4 & 0 & 5 \\
\hline Molossidae $_{\text {\&\& }}$ & 0 & 0 & 0 & 1 & 2 & 8 & 11 & 2 & 67 & 20 & 100 \\
\hline Mormoopidae (ns) & 0 & 0 & 0 & 1 & 0 & 0 & 1 & 0 & 8 & 0 & 9 \\
\hline Mystacinidae (ns) & 0 & 0 & 0 & 1 & 0 & 1 & 2 & 0 & 0 & 0 & 2 \\
\hline Myzopodidae (ns) & 0 & 0 & 0 & 0 & 0 & 0 & 0 & 0 & 2 & 0 & 2 \\
\hline Natalidae (ns) & 0 & 0 & 0 & 2 & 0 & 0 & 2 & 4 & 5 & 0 & 11 \\
\hline Noctilionidae (ns) & 0 & 0 & 0 & 0 & 0 & 0 & 0 & 0 & 2 & 0 & 2 \\
\hline Nycteridae (ns) & 0 & 0 & 0 & 0 & 0 & 1 & 1 & 1 & 10 & 4 & 16 \\
\hline Phyllostomidae \&\&\& & 3 & 0 & 3 & 1 & 5 & 12 & 18 & 12 & 121 & 22 & 176 \\
\hline Pteropodidae*** & 4 & 0 & 4 & 9 & 18 & 38 & 65 & 14 & 82 & 22 & 187 \\
\hline Rhinolophidae ${ }^{\&}$ & 0 & 0 & 0 & 1 & 4 & 5 & 10 & 6 & 47 & 11 & 74 \\
\hline Rhinopomatidae (ns) & 0 & 0 & 0 & 0 & 0 & 0 & 0 & 0 & 3 & 1 & 4 \\
\hline
\end{tabular}




\begin{tabular}{|c|c|c|c|c|c|c|c|c|c|c|c|}
\hline FAMILY & EX & EW & 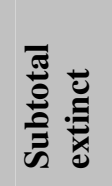 & $\mathbf{C R}$ & $\mathbf{E N}$ & VU & 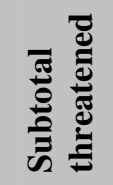 & NT & $\mathbf{L C}$ & DD & 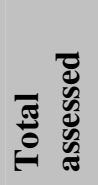 \\
\hline Thyropteridae (ns) & 0 & 0 & 0 & 0 & 0 & 0 & 0 & 0 & 2 & 2 & 4 \\
\hline Vespertilionidae $e^{\& \& \&}$ & 0 & 0 & 0 & 7 & 17 & 20 & 44 & 30 & 251 & 96 & 421 \\
\hline Total Chiroptera & 7 & $\mathbf{0}$ & 7 & 25 & 53 & 99 & 177 & 77 & 687 & 204 & 1152 \\
\hline \multicolumn{12}{|l|}{ PHOLIDOTA (ns) } \\
\hline Manidae (ns) & 0 & 0 & 0 & 0 & 2 & 0 & 2 & 4 & 2 & 0 & 8 \\
\hline \multicolumn{12}{|l|}{ CARNIVORA (ns) } \\
\hline Ailuridae (ns) & 0 & 0 & 0 & 0 & 0 & 1 & 1 & 0 & 0 & 0 & 1 \\
\hline Canidae (ns) & 1 & 0 & 1 & 3 & 3 & 0 & 6 & 4 & 24 & 1 & 36 \\
\hline Eupleridae (ns) & 1 & 0 & 1 & 0 & 1 & 3 & 4 & 3 & 1 & 0 & 9 \\
\hline Felidae* $^{\star}$ & 0 & 0 & 0 & 1 & 6 & 9 & 16 & 9 & 11 & 0 & 36 \\
\hline Herpestidae ${ }^{\&}$ & 0 & 0 & 0 & 0 & 0 & 3 & 3 & 1 & 27 & 3 & 34 \\
\hline Hyaenidae (ns) & 0 & 0 & 0 & 0 & 0 & 0 & 0 & 2 & 2 & 0 & 4 \\
\hline Mephitidae (ns) & 0 & 0 & 0 & 0 & 0 & 1 & 1 & 0 & 11 & 0 & 12 \\
\hline Mustelidae (ns) & 1 & 0 & 1 & 0 & 7 & 5 & 12 & 4 & 36 & 6 & 59 \\
\hline Nandiniidae (ns) & 0 & 0 & 0 & 0 & 0 & 0 & 0 & 0 & 1 & 0 & 1 \\
\hline Odobenidae $^{2}$ & 0 & 0 & 0 & 0 & 0 & 0 & 0 & 0 & 0 & 1 & 1 \\
\hline Otariidae (ns) & 1 & 0 & 1 & 0 & 4 & 2 & 6 & 2 & 7 & 0 & 16 \\
\hline Phocidae (ns) & 1 & 0 & 1 & 2 & 1 & 1 & 4 & 0 & 12 & 2 & 19 \\
\hline Prionodontidae (ns) & 0 & 0 & 0 & 0 & 0 & 0 & 0 & 0 & 2 & 0 & 2 \\
\hline Procyonidae (ns) & 0 & 0 & 0 & 1 & 0 & 0 & 1 & 0 & 10 & 3 & 14 \\
\hline Ursidae** & 0 & 0 & 0 & 0 & 1 & 5 & 6 & 0 & 2 & 0 & 8 \\
\hline Viverridae (ns) & 0 & 0 & 0 & 1 & 1 & 9 & 11 & 2 & 17 & 3 & 33 \\
\hline Total Carnivora & 5 & $\mathbf{0}$ & 5 & 8 & 24 & 39 & 71 & 27 & 163 & 19 & 285 \\
\hline \multicolumn{12}{|c|}{ PERISSODACTYLA **** } \\
\hline Equidae* & 0 & 0 & 0 & 2 & 2 & 1 & 5 & 0 & 2 & 0 & 7 \\
\hline Rhinocerotidae* & 0 & 0 & 0 & 3 & 0 & 1 & 4 & 1 & 0 & 0 & 5 \\
\hline Tapiridae** & 0 & 0 & 0 & 0 & 3 & 1 & 4 & 0 & 0 & 0 & 4 \\
\hline Total Perissodactyla & $\mathbf{0}$ & $\mathbf{0}$ & $\mathbf{0}$ & 5 & 5 & 3 & 13 & 1 & 2 & $\mathbf{0}$ & 16 \\
\hline
\end{tabular}




\begin{tabular}{|c|c|c|c|c|c|c|c|c|c|c|c|}
\hline FAMILY & EX & EW & 吾 & $\mathbf{C R}$ & EN & $\mathbf{V U}$ & 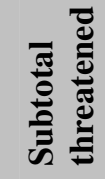 & NT & LC & DD & 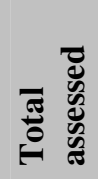 \\
\hline \multicolumn{12}{|c|}{ CETARTIODACTYLA $* * * *$} \\
\hline Antilocapridae (ns) & 0 & 0 & 0 & 0 & 0 & 0 & 0 & 0 & 1 & 0 & 1 \\
\hline Balaenidae (ns) & 0 & 0 & 0 & 0 & 2 & 0 & 2 & 0 & 2 & 0 & 4 \\
\hline Balaenopteridae (ns) & 0 & 0 & 0 & 0 & 3 & 0 & 3 & 0 & 2 & 3 & 8 \\
\hline Bovidae*** & 4 & 1 & 5 & 8 & 20 & 21 & 49 & 16 & 67 & 3 & 140 \\
\hline Camelidae (ns) & 0 & 0 & 0 & 1 & 0 & 0 & 1 & 0 & 2 & 0 & 3 \\
\hline Cervidae*** & 1 & 1 & 2 & 1 & 7 & 16 & 24 & 2 & 17 & 10 & 55 \\
\hline Delphinidae (ns) & 0 & 0 & 0 & 0 & 1 & 2 & 3 & 3 & 13 & 16 & 35 \\
\hline Eschrichtiidae (ns) & 0 & 0 & 0 & 0 & 0 & 0 & 0 & 0 & 1 & 0 & 1 \\
\hline Giraffidae (ns) & 0 & 0 & 0 & 0 & 0 & 0 & 0 & 1 & 1 & 0 & 2 \\
\hline Hippopotamidae** & 2 & 0 & 2 & 0 & 1 & 1 & 2 & 0 & 0 & 0 & 4 \\
\hline Iniidae (ns) & 0 & 0 & 0 & 1 & 0 & 1 & 2 & 0 & 0 & 1 & 3 \\
\hline Monodontidae (ns) & 0 & 0 & 0 & 0 & 0 & 0 & 0 & 2 & 0 & 0 & 2 \\
\hline Moschidae*** & 0 & 0 & 0 & 0 & 6 & 1 & 7 & 0 & 0 & 0 & 7 \\
\hline Neobalaenidae $^{2}$ & 0 & 0 & 0 & 0 & 0 & 0 & 0 & 0 & 0 & 1 & 1 \\
\hline Phocoenidae (ns) & 0 & 0 & 0 & 1 & 0 & 1 & 2 & 0 & 2 & 2 & 6 \\
\hline Physeteridae (ns) & 0 & 0 & 0 & 0 & 0 & 1 & 1 & 0 & 0 & 2 & 3 \\
\hline Platanistidae (ns) & 0 & 0 & 0 & 0 & 1 & 0 & 1 & 0 & 0 & 0 & 1 \\
\hline Suidae** & 0 & 0 & 0 & 2 & 3 & 5 & 10 & 1 & 6 & 1 & 18 \\
\hline Tayassuidae (ns) & 0 & 0 & 0 & 0 & 1 & 0 & 1 & 1 & 1 & 1 & 4 \\
\hline Tragulidae (ns) & 0 & 0 & 0 & 0 & 1 & 0 & 1 & 0 & 6 & 3 & 10 \\
\hline Ziphiidae (ns) & 0 & 0 & 0 & 0 & 0 & 0 & 0 & 0 & 2 & 19 & 21 \\
\hline Total Cetartiodactyla & 7 & 2 & 9 & 14 & 46 & 49 & 109 & 26 & 123 & 62 & 329 \\
\hline
\end{tabular}

Significantly more threatened than expected: $* * * \mathrm{p}<0.001 ; * * \mathrm{p}<0.01 * \mathrm{p}<0.5$.

Significantly less threatened than expected: ${ }^{\& \& \&} \mathrm{p}<0.001 ;{ }^{\& \&} \mathrm{p}<0.01 ;{ }^{\&} \mathrm{p}<0.5$.

(ns) - non significant; ${ }^{1}$ all species Extinct; ${ }^{2}$ all species Data Deficient. 


\subsection{Main types of threat}

Table S2: Number and percentage of species affected by each of six main threat categories. Species can be affected by more than one threat category; being affected by a threat does not necessarily imply that the species is globally threatened (Vulnerable, Endangered, or Critically Endangered). Land and marine species are those mapped in Fig. 1, and exclude 78 extinct and 14 Data Deficient species; seven species are mapped as both land and marine.

\begin{tabular}{llllllll}
\hline & All & \multicolumn{7}{c}{ Threat } \\
\cline { 2 - 7 } & $\begin{array}{l}\text { assessed/ } \\
\text { mapped }\end{array}$ & $\begin{array}{l}\text { Habitat } \\
\text { loss }(\boldsymbol{\%})\end{array}$ & $\begin{array}{l}\text { Utilisation } \\
(\boldsymbol{\%})\end{array}$ & $\begin{array}{l}\text { Accidental } \\
\text { mortality } \\
(\%)\end{array}$ & $\begin{array}{l}\text { Pollution } \\
(\%)\end{array}$ & $\begin{array}{l}\text { Invasive } \\
\text { species } \\
(\%)\end{array}$ & $\begin{array}{l}\text { Disease } \\
(\%)\end{array}$ \\
\hline $\begin{array}{l}\text { All } \\
\text { mammals }\end{array}$ & 5,487 & $2,030(37)$ & $926(17)$ & $284(5)$ & $219(4)$ & $309(6)$ & $117(2)$ \\
$\begin{array}{l}\text { Land } \\
\text { mammals }\end{array}$ & 5,282 & $2,016(38)$ & $872(17)$ & $193(4)$ & $151(3)$ & $306(6)$ & $102(2)$ \\
$\begin{array}{l}\text { Marine } \\
\text { mammals }\end{array}$ & 120 & $2(2)$ & $61(51)$ & $98(82)$ & $75(63)$ & $3(3)$ & $16(13)$ \\
\hline
\end{tabular}




\subsection{New species descriptions}

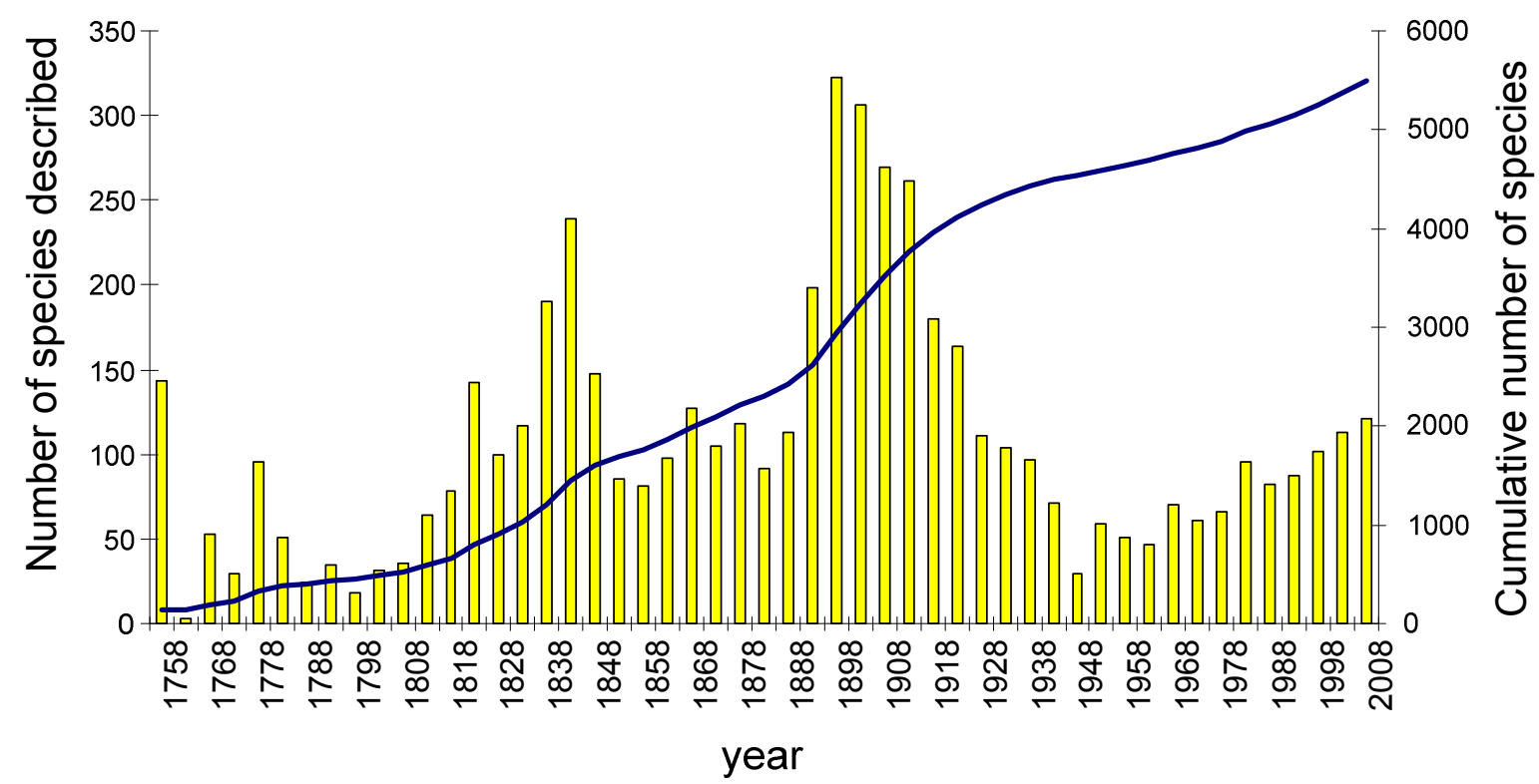

Fig. S8. Number of species described per five-year interval (yellow bars) and cumulative total number of species currently recognized as taxonomically valid (blue line) (adapted from ref. 27). The first column corresponds to all species recognised up to 1758 . 


\section{References and notes}

1. A. S. L. Rodrigues et al., Trends Ecol. Evol. 21, 71-76 (2006).

2. S. N. Stuart et al., Science 306, 1783-1786 (2004).

3. K. Carpenter et al., Science 321, 560-563 (2008).

4. IUCN 1996 IUCN Red List of Threatened Animals (IUCN Gland, Switzerland, 1996).

5. IUCN, IUCN Red List Categories \& Criteria (version 3.1) (IUCN, Gland, Switzerland, 2001) http://www.iucnredlist.org/info/categories_criteria2001.

6. For a list of Specialist Groups and Chairs, and links to action plans, see: http://cms.iucn.org/about/work/programmes/species/working_together/specialist_gro ups/directory_specialist_groups/directory_sg_mammals/index.cfm.

7. For a list of published actions plans, see: http://cms.iucn.org/about/work/programmes/species/resources/publications/species_a ctions_plans/index.cfm.

8. D.E. Wilson, D.A. Reeder, Mammal Species of the World: A Taxonomic and Geographic Reference, $3^{\text {rd }}$ edn (Johns Hopkins Univ. Press, Baltimore, 2005).

9. K.P. Koepfli et al., BMC Biology 6, 10 (2008).

10. U. Radespiel et al., Am. J. Primatol. 70, 1-14 (2008).

11. J. Gatesy et al., Mol. Biol. \& Evol. 13, 954-963 (1996).

12. M. Nikaido et al., Proc. Natl. Acad. Sci. U.S.A. 96, $10261-10266$ (1999). 
13. W.J. Murphy et al., Science 294, 2348-2351 (2001).

14. H. Amrine-Madsen et al., Mol. Phylog. \& Evol. 28, 225-240 (2003).

15. U. Arnason et al., Gene 333, 27-34 (2004).

16. J.H. Geisler, M.D. Uhen, J. Mamm. Evol. 12, 145-160 (2005).

17. J.D. Archibald, Mol. Phylog. \& Evol. 28, 350-359 (2003).

18. W. W. Sechrest, Global Diversity, Endemism and Conservation of Mammals, Thesis. University of Virginia, Charlottesville, USA (2003).

19. See http://www.iucnredlist.org/info/major_habitats.

20. See http://www.iucnredlist.org/info/major_threats.

21. See http://www.iucnredlist.org/info/conservation_actions.

22. See http://www.iucn.org/themes/ssc/sis/authority.htm.

23. S. H. M. Butchart et al., Phil. Trans. Soc. B 360, 255-268 (2005).

24. M. Hoffmann et al., Endanger. Species Res. 7 May 2008 (10.3354/esr00087).

25. P. C. De Grammont, A. D. Cuarón, Conserv. Biol. 20, 14-27 (2006).

26. D. E. Wilson \& D.A. Reeder, Mammal Species of the World: A Taxonomic and Geographic Reference, $2^{\text {nd }}$ edn (Smithsonian Institution Press, Washington, DC., 1993).

27. D. M. Reeder, K. M. Helgen, D. E. Wilson, Occas. Pap. Museum Texas Tech Univ. 269, 1-35 (2007). 
28. B. D. Patterson Nature 380, 589 (1996).

29. F. Rovero et al., J. Zool. 274, 126-133 (2008).

30. S. M. Goodman et al., Mamm. Biol. 73, 199-213 (2008).

31. J. P. Boubli et al., Int. J. Primatol. 29, 723-741 (2008).

32. J. E.M. Baillie et al., Global Species Assessment (IUCN, Gland, Switzerland, 2004).

33. A. H. Hulbert, W. Jetz, Proc. Natl. Acad. Sci. U.S.A. 104, 13384-13389 (2007).

34. J. Powell, Manatees in the Bijagos Archipelago: Recommendations for Their Conservation (IUCN Wetland Programme., Gland, Switzerland, 1990).

35. M. Kienta, Preliminary Investigations on the manatee (Trichechus senegalensis) at Lac Deb, Mali, West Africa (1985).

36. H. Kruuk, Wild Otters (Oxford Univ. Press, Oxford, UK, 1995).

37. T. Flannery, Mammals of New Guinea (Reed Books, Chatswood, NSW, Australia, 1995).

38. K. Sahr, D. White, A. J. Kimerling, Cartography and Geographic Information Science. 30, 121-134 (2003).

39. C. P. Birch, S. P. Oom, J. A. Beecham, Ecol. Model. 206, 347-359 (2007).

40. D. M. Olson et al., BioScience. 51, 933-938 (2001).

41. O. R. P. Bininda-Emonds et al., Nature. 446, 507-512 (2007).

42. D. Faith, Biol. Conserv. 61, 1-10 (1992). 
43. D. P. Faith, Philos. Trans. R. Soc. London B. 345, 45-58 (1994).

44. A. S. L. Rodrigues, K. J. Gaston, Biol. Conserv. 105, 103-111 (2002).

45. A. J. Stattersfield, M. J. Crosby, A. J. Long, D. C. Wege, Endemic Bird Areas of World: Priorities for Biodiversity Conservation (BirdLife International, Cambridge, UK, 1998).

46. C. D. L. Orme et al., Nature. 436, 1016-1019 (2005).

47. R. Grenyer et al., Nature. 444, 93-96 (2006).

48. B. A. Hawkins, J. A. F. Diniz-Filho, Global Ecol. Biogeogr. 15, 461-469 (2006).

49. C. D. L. Orme et al., PLoS Biology. 4, e208 (2006).

50. G. M. Mace et al., Conserv. Biol. (in press).

51. S. L. Pimm, G. J. Russell, J. L. Gittleman, T. M. Brooks, Science. 269, 347-350 (1995). 


\section{Acknowledgements}

\subsection{Institutional Support}

This project would not have been possible without the generous support of numerous partner organizations. The International Union for Conservation of Nature (IUCN) and Conservation International (CI) led this effort and provided significant direct support throughout. Both CI and IUCN shared in equipping, housing, and staffing the project during its various phases.

We gratefully acknowledge the support of the Gordon and Betty Moore Foundation and the Moore Family Foundation, which provided core funding to CI, supporting workshops, staff salaries, and day-to-day operations. Special thanks are due to the Critical Ecosystem Partnership Fund (CEPF), providing as it did the initial funding to employ a full-time project manager, enabling the project to get underway. Jorgen Thomsen, Donnell Ocker, Bobbie Jo Kelso, Dan Martin, and Michele Zador facilitated this support.

The Istituto di Ecologia Applicata (IEA), University of Rome, received major support from the European Commission and from within the IUCN Species Survival Commission (SSC) network. This resulted in seven successful workshops in Southeast Asia. Major support to the Sapienza Università di Roma came from unrestricted research funds granted to several authors. We especially thank them for their unfailing contributions to the IUCN Red List assessments of the mammals, and for providing much staff time.

Texas A\&M University and Texas A\&M AgriLife Extension provided major support for both staff salaries and participation in workshops. Major support for the Zoological Society of London (ZSL) was provided by USAID's Central African Regional Program for the Environment (CARPE) and Elsevier. At Arizona State University, the School of Life Sciences, Global Institute of Sustainability, Center for Biology and Society, College 
of Liberal Arts and Sciences, and Vice-president for Research and Economic Affairs provided significant financial contributions.

We also acknowledge the University of Virginia (UVA) for its financial support of the project when it was based in its Department of Environmental Sciences. Dr. Ariel Gomez, UVA's Vice President for Research and Graduate Studies, and his staff were instrumental in this partnership.

\section{Workshop Donors}

We conducted 27 workshops; each contingent upon financial support of donors (for a complete list see the "Methods" in the Supplementary online information). We acknowledge these donors, as well as those individuals (in parentheses) who helped facilitate grant acquisition. We also express our utmost gratitude to all of the IUCN/SSC Specialist Groups for mammals, members of which participated in the workshops and were responsible for coordinating assessments for their respective species groups.

The Africa workshops for small mammals were supported by CEPF, Elsevier (Andy Richford), CARPE (Juan Carlos Bonilla and John Flynn), and IEA. African Primates were assessed with support from CARPE, the Margot Marsh Biodiversity Foundation (Bill Konstant), and Disney's Animal Programs (Anne Savage). The mammals of Madagascar were assessed with support from the CI-Madagascar CBC (Leon Rajaobelina and Frank Hawkins).

Southwest Asian mammals were assessed with financial support from CEPF. Mongolian mammal assessments were conducted with funds provided by the World Bank's Netherlands-Mongolia Trust Fund for Environmental Reform, ZSL, the National University of Mongolia, the Mongolian Academy of Sciences, the Ministry of Nature and Environment - Mongolia, IUCN, the Wildlife Conservation Society, the Darwin Initiative, Denver Zoo, WWF, the University of Nebraska, and Hustai National Park. A workshop in South Asia to assess non-volant small mammals was supported by the Zoo Outreach Organization (ZOO), India. 
Numerous workshops (including those for the small carnivores and Asian primates) were conducted across Southeast Asia and the Philippines in partnership with IEA, through the Southeast Asia Mammal Databank project that is co-funded by the EC. The mammals of Japan were assessed with funds from OFEV. The assessments of the mammals of Australia, Melanesia, and the Pacific Islands were made possible by the Australian Wildlife Conservancy (Atticus Fleming) and CI-Melanesia (François Martel, Bruce Beehler, and Gaikovina Kula).

European Mammals were assessed by a sister project-the European Mammal Assessment (EMA), a regional workshop funded by the EC and the Austrian Federal Ministry of Agriculture, Forestry Environment, and Water. The full list of acknowledgements for the EMA is available online: http://ec.europa.eu/environment/nature/conservation/species/ema/acknowledge.htm.

Small mammals of the Andes were assessed with support from Conservation International's (CI) Andes Center for Biodiversity Conservation (CBC), and the CI regional programs in Mesoamerica, Mexico and the Caribbean, with support from CEPF, the United States Fish and Wildlife Service, the Lubee Foundation (Allyson Walsh), and El centro Zamorano de Biodiversidad. Small mammals from the Southern Cone were assessed with support from the US Department of State Voluntary Contribution to IUCN. The Brazil and Guianas' workshop and the edentates workshop were financed by the Brazil-Guianas CBC. Assessments of Neotropical primates were funded by the Margot Marsh Biodiversity Foundation (Bill Konstant) and Disney's Animal Programs (Anne Savage).

The cetacean workshop was funded by CI through its Global Marine Program (Roger McManus), SeaWorld \& Busch Gardens Conservation Fund, and the United States Voluntary Contribution to IUCN. We recognize the financial contribution of the US Marine Mammal Commission to the cetacean workshop and the pinniped assessments, and for supporting the Sirenia workshop along with CI's Global Marine Program. The cat 
workshop was made possible by a generous contribution from the Panthera Foundation (Tom Kaplan).

We acknowledge the IUCN/SSC Conservation Breeding Specialist Group (CBSG) and 150 conservation organizations worldwide that have provided institutional and/or financial support to conduct Population and Habitat Viability Assessment (PHVA) Workshops for the four species of tapir between 2003 and 2007. In addition assessments of Mexican lagomorphs were provided by AMCELA - The Mexican Association for the Study and Conservation of Lagomorphs.

The European Commission (EC) provided support for the assessment of European and Southeast Asian species. Funding for the Mediterranean workshop was kindly provided by the MAVA foundation. We are grateful to Switzerland's Office fédéral de

l'environnement (OFEV), in particular Olivier Biber, and to the US State Department which provided financial support at a very crucial stage of the process.

\section{Conservation Partners}

This assessment of the threatened status of the Class Mammalia was made possible not only by funding, but by a network of partnerships between institutions and individuals. A huge debt is owed to a number of staff in the IUCN Species Programme who supported the project over the last five years. We particularly thank Jane Smart, Dena Cator, Julie Griffin, Bryan Hugill, Lynette Lew, Hugo Ruiz Lozano, Claire Santer, and Doreen Zivkovic for both administrative and technical support. Thanks are also due to Susannah O'Hanlon and Leah Collett, as well as IUCN volunteers Philip Martin and James Beresford, who provided much-needed GIS support in the final stages of the project.

At CI, we thank the following people for providing regional and local logistic support for workshops and for coordination of species assessments and species experts: Mohamed Bakarr, Jim Barborak, Daniel Brito, Don Church, Jaime García-Moreno, Claude Gascon, Roger James, Jill Lucena, Laara Manler, Ella Outlaw, Carlos Manuel Rodriguez, Conrad Savy, and Will Turner. 
For several years, the GMA was housed at UVA through a Memorandum of Understanding signed between CI and the Vice President for Research and Graduate Studies at UVA, Ariel Gomez. We are grateful to Ariel Gomez for his hospitality during the time that the project was based there. At UVA Hank Shugart helped provide day-today oversight, and Cindy Allen, Sarah Alspaugh, Michael Erwin, Lyndon Estes, Lelia Gibson, Jann Goetzman, James Green, Pam Hoover, Mike Knetzger, Grace Lipscomb, Steve Macko, Carleton Ray, Robert Swap, Sam Truslow, Henry White, Jack Wisman, Charlotta Wriston, and Joseph Ziemen provided intellectual input and technical support. A special word of thanks is due to Jennifer Law and Tamar Samuel Siegel for their assistance in keeping the project running, and to Will Tomanek and Robert WashingtonAllen, who helped in problem solving and computer applications.

The taxonomic foundation of this project, as mentioned elsewhere, owes much to the efforts of the editors and authors of the $3^{\text {rd }}$ edition of Mammal Species of the World (MSW). We are most grateful to Don Wilson, DeeAnn Reeder, Nancy Simmons, Robert Hoffmann, Guy Musser, Michael Carleton, Sydney Anderson, Richard Thorington, Jr., Robert Voss and all of the other authors for providing advance drafts of their manuscripts and species lists that proved so useful at the beginning stages of the project (2003 to 2004). We also take this opportunity to pay tribute to the late Jeheskel (Hezy) Shoshani, Peter Grubb and W. Chris Wozencraft, all MSW authors and active members of IUCN/SSC Specialist Groups. We thank Sam Turvey for making unpublished data available at critical periods particularly based on his work on Holocene mammal extinctions and for support of the assessment process at workshops and elsewhere.

IEA and the Department of Human and Animal Biology at Sapienza Università di Roma formed the Southeast Asia Mammal Databank (SAMD) project, which partnered with this project to share data and funding. The partnership was supported by The ASEAN Center for Biodiversity, Institute of Biology of the University of the Philippines Diliman, Indonesian Institute of Sciences (LIPI), and the Vietnamese Institute of Ecology and Biological Resources. 
We thank Robert Pressey for numerous stimulating discussions at various phases of the the project. We also recognize Ken Aplin, Kaycie Billmark, Olaf Bininda-Emonds, Chris Carbone, Marcel Cardillo, Justin O’Dell, Eric Dinerstein, Richard Estes, John Gittleman, Kate Jones, Darrin Lunde, Charlie Nunn, John Morrison, John Pilgrim, Samantha Price, Andy Purvis, Ronald Strahan for their technical inputs and guidance.

Ana Rodrigues was funded by a Fundação para a Ciência e Tecnologia Postdoctoral Fellowship (Portugal). Jan Schipper and Beth Polidoro were partially funded by NSFIGERT Grant No. 0114304.

Workshops were kindly hosted by the following institutions (geographic or taxonomic groups of mammals assessed are in parentheses): ZSL (African small mammals), BrazilGuianas CBC (edentates), Disney's Animal Programs (African and Neotropical primates), CI Madagascar CBC (Madagascar), 9th International Mammalogical Congress (Sirenia), CI-Japan (Japan), South Australian Museum (Australia/Pacific), Fundação Biodiversitas (Brazil/Guianas and Southern Cone), Hustai National Park (Mongolia), IEA (Southeast Asia small mammals), El Instituto Alexander von Humboldt (Andes), the Wildlife Conservation Society of the Philippines, CI-Philippines, and the Katala Foundation (Philippines), CI-Indonesia (Southeast Asia large mammals and bats), the American Museum of Natural History, New York (Southeast Asian rodents), Cuc Phuong National Park and Owston's Civet Conservation Program (small carnivores), CI-IndoBurma (Asian primates), IUCN Centre for Mediterranean Cooperation (Mediterranean), the Scripps Institution of Oceanography and Southwest Fisheries Science Center, NOAA, NMFS (Cetaceans), the Wildlife Conservation Research Unit of Oxford University (cats), and the Escuela Agrícola Panamericana, Carrera de Desarrollo Socioeconómico y Ambiente, and El Centro Zamorano de Biodiversidad (Mesoamerica, Mexico and Caribbean small mammals).

The following people provided local logistical support or helped facilitate at the assessment workshops: Adriano Paglia (edentates); Anne Savage, Jeanne Ford, Kim Sams, Katie Leighty (African primates and Neotropical primates); Indira Lacerna, Jeanne 
Tabangay, Peter Widmann (Philippines); Harison Randrianasolo (Madagascar); Cyndi Taylor (Sirenia); Yasushi Hibi, Wakako Ichikawa, Hiromi Tada (Japan); John Pilgrim (Australia/Pacific); Güven Eken, Kerem Boyla (Southwest Asia); Darrin Lunde (Southeast Asia rodents); Scott Roberton, Tran Quang Phuong (small carnivores); Olivia Bittencourt, Gláucia Drummond, Eduardo Du Figueiredo, Maria Aparecida da Costa, Helder Galvão Pereira (South American small mammals); Martua Sinaga, Maria Elisa Hobbelink (large mammals and bats of Southeast Asia); Jake Brunner, Anthony Simms, Un Nalene (Asian primates); Sarah Mesnick, Autumn-Lynn Harrison, Suzanne Livingstone (cetaceans); Richard Mercer, Andrew Loveridge, Alexandra Zimmermann (cats); and Jorge Ivan Restrepo and Suyapa Triminio Meyer (Mesoamerican, Mexican and Caribbean small mammals).

In addition to the workshops, maps and information provided by the Chinese Species Information Service were instrumental in constructing accounts of many, if not most, of the Chinese mammals.

The concept of this project, formerly referred to as the Global Mammal Assessment (GMA), and the partnerships that resulted, arose from a working group and workshop hosted by the National Center for Ecological Analysis and Synthesis (University of California, Santa Barbara) entitled "Towards a Global Database of Terrestrial Vertebrate Distributions, Mammals Subgroup”, February 4-7, 2002.

\subsection{Contributing Scientists}

Extraordinary, voluntary commitment from leading experts is the backbone of IUCN's species assessment process. The assessment of the mammals is no exception, being entirely due to extraordnarily generous contributions of the time and expertise of more than 1,700 mammalogists from over 130 countries, many of them members of IUCN/SSC Specialist Groups. It is impossible to overstate the importance of these dedicated individuals-without them the current summary of conservation status for this major class of animals would not have been possible. We have tried to record their information faithfully, and we take full responsibility for errors contained within the assessments. It is 
our hope that the information will be refined, consolidated and updated over time. We express our gratitude to the following people, asking for forgiveness from anyone whose name has been inadvertently omitted: 
Abba, A.

Abdel-Rahman, E.H.

Abe, $\mathrm{H}$.

Abramov, A.

Abril, V.

Abu Baker, M.A.

Acosta, G.

Aguiar, L.M.S.

Aguilar, A.

Aguilera, M.

Aguirre, L.

Agwanda, B.

Ahlmann, V.

Ahmed, B.

Ahrestani, F.

Akhtar, N.

Al Dosary, M.

Al Habhani, H.M.

Al Khaldi, A.

Al Mutairi, M.S.

Al Nuaimi, A.

Alava, M.

Albuja, L.

Alburo, $\mathrm{H}$.

Alcala, E.

Alcaldé, J.

Ali, A.

Ali, R.

Alkon, $\mathrm{P}$.

Allison, A.

Altıparmak, A.

Altrichter, M.

Alvarez, R.

Álvarez, S.

Álvarez-Castañeda, S.T.

Alves de Oliveira, J.

Alves, $\mathrm{P}$.
Alviola, P.

Amano, M.

Amanzo, J.

Ambal, R.G.

Ambrose, L.

Amgalanbaatar, $\mathrm{S}$.

Amir, O.

Amr, Z.

Anacleto, T.

Ancrenaz, M.

Andayani, N.

Andelt, W.

Anderson, J.

Anderson, M.

Anderson, $P$.

Anderson, R.

Andrainarivo, $\mathrm{C}$.

Andrews, $\mathrm{H}$.

Andriafidison, D.

Andriaholinirina, V.

Andriamanana, $\mathrm{R}$.

Andriamaro, L.

Andriambololona, M.

Andriamialison, $\mathrm{H}$.

Andriamifidison, D.

Andriamihaja, B.

Andrianarisata, M.

Andrianjakarivelo, $\mathrm{V}$.

Andriantsilavo, $\mathrm{F}$.

Angelici, $F$.

Angerbjörn, A.

Aplin, K.

Appleton, B.

Arboleda, I.

Ario, A.

Arison, $\mathrm{R}$.

Ariunbold, J.
Armstrong, K.

Arroyo-Cabrales, J.

Arumugam, R.

Asa, C.

Ashenafi, Z.

Assogbadjo, A.

Astua de Moraes, D.

Atickem, A.

Atkinson, R.

Aulagnier, S.

Aune, K.

Aurioles, D.

Avirmed, D.

Azlan, A.

Azlan, M.J.

Babon, M.

Baigún, R.

Baird, R.

Baker, C.

Baker, J.

Baker, L.

Balangcod, T.

Baldwin, R.

Balete, D.

Balfour, D.

Ballesteros, F.

Balmforth, Z.

Baloyan, S.

Banks, P.

Bannister, J.

Bantel, C.

Baoanan

Baral, H.S.

Barashkova, A.

Bargali, $\mathrm{H}$.

Barış, S.

Barlow, J. 


\begin{tabular}{|c|c|c|}
\hline Barnett, A. & Berggren, $\mathrm{P}$. & Boonratana, R. \\
\hline Barney, L. & Bergl, R. & Born, E. \\
\hline Barquez, R. & Bergmans, W. & Borroto-Paez, R. \\
\hline Barrio, J. & Bergstrom, B. & Bose, J. \\
\hline Barry, R. & Bernal, N. & Bosworth, W. \\
\hline Bartels, P. & Bernard, E. & Botello, J. \\
\hline Barua, M. & Bertolino, S. & Boubli, J.P. \\
\hline Batbold, J. & Best, P. & Bóveda-Penalba, A. \\
\hline Bates, P.J.J. & Bestelmeyer, S. & Bowler, M. \\
\hline Batin, G. & Beyer, A. & Boyd, C. \\
\hline Batsaikhan, N. & Bhat, H.R. & Boyd, L. \\
\hline Bauer, $\mathrm{H}$. & Bhatnagar, Y. & Boyer, A. \\
\hline Baxter, R. & Bhatta, T. & Boyla, K. \\
\hline Bayarkhuu, S. & Bhattacharyya, T. & Bozdogan, M. \\
\hline Bayarmaa & Bidau, C. & Brandle, R. \\
\hline Bayartoghtokh, B. & Biggins, D. & Brandon-Jones, D. \\
\hline Bazardorj, D. & Bila-Isia, I. & Braulik, G. \\
\hline Bearder, S. & Birkun, A. & Breed, W. \\
\hline Bearzi, G. & Bist, S. & Breitenmoser, U. \\
\hline Beauvais, G. & Bisther, $\mathrm{M}$. & Breitenmoser-Würsten, C. \\
\hline Beccaceci, M. & Biswas, J. & Brescia, F. \\
\hline Beck, H. & Bittencourt, O. & Brickle, N. \\
\hline Beckmann, J. & Bivash P. & Brito, D. \\
\hline Beever, E. & Bjørge, A. & Brockelman, W. \\
\hline Begg, C. & Bleisch, W. & Bronner, G. \\
\hline Begg, K. & Blois, J. & Brooke, A. \\
\hline Bekoff, M. & Blom, A. & Brooks, D. \\
\hline Belant, J. & Bloomer, P. & Broome, L. \\
\hline Belant, L. & Boada, C. & Brown, D. \\
\hline Belbachir, F. & Bocian, C. & Brown, M. \\
\hline Bello, J. & Boeadi & Brownell Jr., R.L. \\
\hline Benda, P. & Boesch, C. & Buden, D. \\
\hline Benishay, J. & Boisserie, J-R. & Budsuren, D. \\
\hline Bennett, D. & Bold, A. & Bukhnikashvili, A. \\
\hline Benshemesh, J. & Bonaccorso, F. & Bumrungsri, S. \\
\hline Berducou, C. & Bonal, B. & Burbidge, A. \\
\hline Bergallo, H. & Bonvicino, C. & Burdin, A. \\
\hline
\end{tabular}




\begin{tabular}{|c|c|c|}
\hline Burkanov, V. & Cervantes, F. & Copley, P. \\
\hline Burneo, S. & Chaiyarat, $\mathrm{R}$. & Corbett, L. \\
\hline Burnett, S. & Chakraborty, S. & Cordero, H.R. \\
\hline Butterworth, D. & Chakravarthy, A.K. & Cornejo, F. \\
\hline Buuveibaatar, V. & Chakravarthy, B. & Coroiu, I. \\
\hline Byers, J. & Chalise, M. & Cortes, J. \\
\hline Cadena, A. & Chalukian, S. & Cortés-Ortiz, L. \\
\hline Cajas, J. & Chan, B. & Corti, M. \\
\hline Camancho, J. & Changappa, K.N. & Corti, P. \\
\hline Camara, C. & Chantrapornsyl, S. & Cossíos, D. \\
\hline Campagna, C. & Chardonnet, P. & Costa, D. \\
\hline Camperio-Ciani, A. & Charles-Dominique, $\mathrm{P}$. & Cotterill, F.P.D. \\
\hline Can, Ö. & Chauhan, N. & Courtenay, J. \\
\hline Cañadas, A. & Chaves, $\mathrm{P}$. & Courtenay, $\mathrm{O}$. \\
\hline Cannings, S. & Chetry, D. & Covert, B. \\
\hline Canty, P. & Chhangani, A.K. & Cox, D. \\
\hline Carbyn, L. & Chiang, $\mathrm{P}$. & Coxe, S. \\
\hline Cardiff, S. & Chiarello, A. & Craig, C. \\
\hline Carey, C. & Chimeddorj, B. & Craul, M. \\
\hline Cariño, A. & Chimed-Ochir, B. & Crawford-Cabral, J. \\
\hline Carino, $\mathrm{P}$. & Chitaukali, W. & Creel, S. \\
\hline Carpenter, K. & Choudhury, A. & Crespo, E. \\
\hline Carraway, L. & Christoff, A. & Crider, D. \\
\hline Carrick, F. & Chundawat, R. & Crowley, $\mathrm{H}$. \\
\hline Carrillo, O. & Cianfrani, C. & Cruz-Aldan, E. \\
\hline Carthew, S. & Cilliers, S. & Csorba, G. \\
\hline Caso, A. & Clapham, P. & Cuarón, A. \\
\hline Cassinello, J. & Clara, M. & Cuéllar, E. \\
\hline Castellanos, A. & Clark, C. & Cumming, D. \\
\hline Castro-Arellano, I. & Clark, E. & Custodio, C. \\
\hline Catling, $P$. & Clausen, M. & Cuzin, F. \\
\hline Catzeflis, F. & Coetzee, C.G. & Cypher, B. \\
\hline Causado, J. & Çolak, E. & da Cruz Neto, A. \\
\hline Cavallini, $\mathrm{P}$. & Collins, K. & Da Silva, V. \\
\hline Ceballos, N. & Collins, $\mathrm{T}$. & Dabek, L. \\
\hline Cerqueira, $\mathrm{R}$. & Constantino, E. & Dalebout, M. \\
\hline Cervancia, M. & Cooper, N. & Dalponte, J. \\
\hline
\end{tabular}




\begin{tabular}{|c|c|c|}
\hline Dalton, $\mathrm{R}$. & de Tores, $\mathrm{P}$. & Dorjgotov, B. \\
\hline Damdin, $\mathrm{T}$. & de Vries, $T$. & Dorjraa, O. \\
\hline Damon, F. & Decher, J. & Doroff, A. \\
\hline Dang, N. & Deka, $\mathrm{P}$. & Doss, D.P.S. \\
\hline Daniel, B.A. & del Pilar Rivas, M. & Dowler, R. \\
\hline Daniel, J.C. & Dela, J. & Downer, C. \\
\hline Daniels, R.J.R. & Delgado, C. & Drew, C. \\
\hline Dans, S. & D'Elia, G. & Driessen, M. \\
\hline Daouda, H. & Dell, J. & Driscoll, C. \\
\hline Darman, Y. & DeLuycker, A. & Drummond, G. \\
\hline Darmaraj, M. & DeMaster, D. & Duarte, J.M.B. \\
\hline Darria, J. & Demirtaş, S. & Dulamtseren, S. \\
\hline Das, J. & Denny, M. & Duncan, J. \\
\hline Dávalos, L. & Desai, A. & Dunham, A. \\
\hline Davenport, $\mathrm{T}$. & Deutsch, C. & Dunlop, R. \\
\hline David, J. & D'Huart, J. & Dunn, A. \\
\hline Dawson, S. & Di fiore, $A$. & Dunnum, J. \\
\hline de A. Goonatilake, & Diaz, A. & Dupain, J. \\
\hline W.L.D.P.T.S. & Díaz, J. & Duplaix, N. \\
\hline de Boer, $\mathrm{H}$. & Diaz, M. & Durant, $\mathrm{P}$. \\
\hline de Bustos, S. & Dickman, C. & Durant, S. \\
\hline de Freitas Netto, R. & Diesmos, A. & Durbin, J. \\
\hline De Fretes, Y. & Dieterlen, F. & Durbin, L. \\
\hline de Gonzalez-Maya, J. & Digana, P.M.C.B. & Duvall, C. \\
\hline DE Grammont, P. & Dinh Thong, V. & Duya, A. \\
\hline de longh, $\mathrm{H}$. & Dirrigl, F.J. & Duya, M. \\
\hline De Jong, Y.A. & Disotell, T. & Dwiyahreni, D. \\
\hline de la Sancha, N. & Ditchfield, A.D. & Easa, $\mathrm{P}$. \\
\hline de la Torre, S. & Dittus, W. & East, $\mathrm{R}$. \\
\hline de Leon, J. & Dixon, $\mathrm{R}$. & Eby, P. \\
\hline De Luca, D. & Do Tuoc & Echenique-Diaz, L. \\
\hline de Oliveira, L. & Doggart, N. & Eeley, $\mathrm{H}$. \\
\hline de Oliveira, M.M. & Dolar, M. & Ehardt, C. \\
\hline de Silva, P. & Dollar, L. & Eizirik, E. \\
\hline de Smet, K. & Domning, D. & Eken, G. \\
\hline de Souza Aguiar, M. & Donovan, G. & Ekué, M. \\
\hline de Thoisy, B. & Dorjderem, S. & Elangovan, $\mathrm{V}$. \\
\hline
\end{tabular}


Elena Kreuzberg, E.

Ellis, C.

Ellis, M.

Ellis, $\mathrm{S}$.

Engstrom, M.

Enkhbat, A.

Ermayanti

Española, C.

Espino Castellanos, L.A.

Esselstyn, J.

Eudey, A.

Evans, $\mathrm{T}$.

Ewel, $\mathrm{K}$.

Eyre, T.

$\mathrm{Fa}$, J.

Fagundes, V.

Fahr, J.

Falanruw, M.

Faria, D.

Farías, V.

Farida, W.

Farmer, K.

Fashing, $P$.

Fasola, L.

Faulhaber, C.

Faulkes, C.

Feeroz, M.M.

Feh, C.

Feistner, A.

Felix, T.

Fellers, G.

Fellowes, J.

Fennessy, J.

Ferguson, M.

Fernandes, M.

Fernandez-Duque, E.

Fernando, $P$.
Ferrari, S.

Ferreira, D.

Ferreyra, N.

Fine, $A$.

Finnie, D.

Finoana, $\mathrm{R}$.

Fiore, A.

Firestone, K.

Fisher, D.

FitzGibbon, C.

Flander, M.

Flannery, $\mathrm{T}$.

Flueck, W.

Foerester, C.

Forbes, $\mathrm{T}$.

Forchhammer, M.

Ford, F.

Ford, J.

Formozov, N.

Forney, K.

Fortuna, C.

Foulkes, J.

Fragoso, J.

Francis, C.

Francis, N.

Franco, M.

Frantzis, A.

Fredriksson, G.

Frey, J.

Friend, $\mathrm{T}$.

Frost, A.

Fruth, B.

Fuller, T.

Funakoshi, K.

Funes, $M$.

Furey, N.

Furuichi, T.
Gaikhorst, G.

Galat, G.

Galat-Luong, A.

Gales, N.

Gallina Tessaro, S.A.

Gallina, S.

Gamarra de Fox, I.

Ganapathiappan, S.

Ganbaatar, O.

Ganbold, D.

Gankhuyag, P.

Gantulga, J.

Ganzhorn, J.

Garbutt, N.

Garcia, H.

Garcia, J.

Garcia-Rangel, S.

Gardner, A.

Garibaldi, A.

Gates, J.

Gatti, S.

Gaubert, P.

Gautier, J.-P.

Gautier-Hion, A.

Gaylord, L.

Geberemedhin, B.

Geffen, E.

G. de S. Wijeyeratne

Geise, L.

Geissmann, T.

Geist, V.

Gelatt, T.

Geraldine, V.

Gerlach, J.

Gese, E.

Ghimire, M.K.

Ghimire, S.C. 
Giannatos, G.

Gil y Carbó, G.

Gill, R.

Giman, B.

Ginsberg, J.

Gippoliti, S.

Girish, A.C.

Girish, D.V.

Gizejewski, Z.

Glowacinski, Z.

Gober, P.

Golden, C.

Goldingay, R.

Goldman, C.

Goldstein, I.

Goldsworthy, S.

Gomez, $\mathrm{H}$.

Gomez, R.

Gómez-Laverde, M.

Gondek, A.

Gongora, J.

Gonzales, A.

Gonzales, J.

González, B.

González, E.

González, J.

Gonzalez, T.

Goodall, R.

Goodman, S.

Goossens, B.

Gopukumar, N.

Gordon, G.

Gordon, J.

Gottelli, D.

Granjon, L.

Grant, T.

Grassman, L.
Gray, M.

Greengrass, E.

Gregorin, R.

Griffin, J.

Griffin, M.

Griffiths, M.

Groenedijk, J.

Groves, C.

Grubb, P.

Guevara, M.

Guineo, G.

Guinet, C.

Guissamulo, A.

Gumal, M.

Gunatilake, S.

Gunawardena, M.

Gunn, A.

Gürsoy, A.

Guttierrez, T.

Habib, B.

Hack, M.

Hadjisterkotis, E.

Hafner, D.

Hafner, M.

Hai Yin, W.

Hajkova, P.

Hall, J.

Hall, L.

Hamilton, $\mathrm{S}$.

Hammer, S.

Han, K.

Handasyde, K.

Hanski, I.

Harding, A.

Harding, L.

Härkönen, T.

Harrison, A.
Hart, J.

Hart, T.

Hashim Abdel Rahman, E.

Hashimoto, C.

Hashimoto, $T$.

Hawkins, A.

Hawkins, F.

Hays, D.

Head, D.

Hearn, A.

Heckel, J.-O.

Hefner, R.

Heide-Joergensen, M.

Heinrich, S.

Henry, J.

Henschel, P.

Henttonen, $\mathrm{H}$.

Herbinger, I.

Herrero, J.

Hersteinsson, $P$.

Heymann, E.

Hicks, C.

Hill, D.

Hill, R.

Hobbelink, M.

Hoces, D.

Hocking, G.

Hoeck, $\mathrm{H}$.

Hofmeyr, G.

Hohmann, G.

Holden, J.

Holdsworth, M.

Holekamp, K.

Hon, J.

Honer, O.

Honess, $\mathrm{P}$.

Horner, $\mathrm{P}$. 


\begin{tabular}{|c|c|c|}
\hline Horsup, A. & Jacobs, D. & Kanchanasaka, B. \\
\hline How, R. & Jakosalem, P. & Kandula, S. \\
\hline Howard, J. & James, D. & Kaneko, Y. \\
\hline Howell, K. & James, R. & Kappeler, P. \\
\hline Hoye, G. & Jansa, S. & Karanth, U. \\
\hline Hoyt, E. & Jaramillo-Legorreta, A. & Karataş, A. \\
\hline Hrabar, H. & Jargal, J. & Karczmarski, L. \\
\hline Htun, S. & Jayat, J.P. & Karki, J.B. \\
\hline Huber, D. & Jdeidi, T. & Kasuya, T. \\
\hline Hucke-Gaete, R. & Jefferson, J. & Kato, $\mathrm{H}$. \\
\hline Huibin, Z. & Jenkins, $P$. & Katuala, P. \\
\hline Humle, T. & Jennings, $A$. & Kauhala, K. \\
\hline Hunt, K. & Jerusalinsky, L. & Kawada, S. \\
\hline Hunter, C. & Jhala, Y.V. & Kawanishi, K. \\
\hline Hunter, L. & Jiang, Z. & Kays, R. \\
\hline Hurley, M. & & Kebede, F. \\
\hline Hutson, A. & Jiménez, J. & Kefelioğlu, H. \\
\hline Hutterer, R. & Jimenez, R. & Kelly, B. \\
\hline Ibuna, M. & Johnsıngh, A. & Kelly, M. \\
\hline llambu, O. & Johnson, K. & Kelt, D. \\
\hline llangakoon, A. & Jonnson, $\mathrm{r}$. & Kemper, C. \\
\hline Immanuel, K. & Jolly, C. & Kemper, K. \\
\hline Incháustegui, S. & Jones, G. & Kendrick, $\mathrm{P}$. \\
\hline Indrawan, M. & Jones, IVI. & Kerbis Peterhans, J. \\
\hline Ingle, N. & Jones, I. & Kerle, A. \\
\hline Insall, D. & Jordan $\mathrm{R}$ & Keuroghlian, A. \\
\hline Irwin, N. & Jordan, n. & Khac Quyet, L. \\
\hline İsfendiyaroğlu, S. & Joseph, G.K. & Khan, A. \\
\hline Is-haquou Daouda, H. & Josin, A. & Khan, J.A. \\
\hline Islam, A. & JOSIII, L.S. & Khan, M.K.M. \\
\hline Islam, M.A. & Josnua, J. & Khorozyan, I. \\
\hline Isnan, W. & Jowkar, H. & Kierulff, M.C.M. \\
\hline Izawa, M. & Jullen-Laterriere, D. & King, S. \\
\hline J. bin Abd. Gulam Azad, A. & Juskalis, n. & Kingston, T. \\
\hline Jackson, D.R. & Juste, J. & Kinnaird, M. \\
\hline Jackson, P. & & Kinoshita, R. \\
\hline Jackson, R. & Kamenva. S. & Kinze, C. \\
\hline
\end{tabular}




\begin{tabular}{|c|c|c|}
\hline Kitchener, D. & Lammertink, M. & Lindsey, $P$. \\
\hline Kittle, A. & Langguth, A. & Link, $\mathrm{A}$. \\
\hline Klingel, $\mathrm{H}$. & Langrand, O. & Linkie, M. \\
\hline Knowlton, F. & Lanjouw, A. & Linzey, A. \\
\hline Kock, D. & Lara-Ruiz, P. & Lippold, L. \\
\hline Kodithuwakku, N.K. & Lastica, E. & Lira-Torres, I. \\
\hline Koenig, K. & Latch, P. & Lissovsky, A. \\
\hline Kofoky, A. & Lau, M. & List, R. \\
\hline Koilraj, A.J. & Launch, A. & Lister, A. \\
\hline Koli, G.H. & Laurenson, M. & Litvaitis, J. \\
\hline Konstant, B. & Lavrenchenko, L. & Liu, A. \\
\hline Koprowski, J.L. & Lawes, M. & Livingstone, S. \\
\hline Korad, V.S. & Lazell, J. & Liyanage, K.R. \\
\hline Kouadio, A. & Le T.T. & Lizcano, D. \\
\hline Kozlowski, A. & Leary, T. & Lkhagvasuren, B. \\
\hline Krajewski, C. & Leasor, H. & Lkhagvasuren, D. \\
\hline Kranz, A. & Lee, B. & Lloyd, P. \\
\hline Kraus, F. & Lehmann, T. & Long, B. \\
\hline Kreb, D. & Lehn, C. & Lopez-Arevalo, H. \\
\hline Krishnamani, R. & Leirs, H. & Lopez-Gonzalez, C. \\
\hline Kryger, U. & Leite, Y. & Lorenzen, E. \\
\hline Kryštufek, B. & Leite-Pitman, M.R.P. & Lorenzo, C. \\
\hline Kukherjee, S. & Lenain, D. & Lorica, M. \\
\hline Kumar Chhangani, A. & Leslie, D. & Lorica, R. \\
\hline Kumar, A. & Lessa, E. & Loucks, C. \\
\hline Kumar, H.R. & Lew, D. & Louis Jr., E. \\
\hline Kumar, S. & Lewis, D. & Lovari, S. \\
\hline Kümpel, N. & Lewison, $\mathrm{R}$. & Loveridge, A. \\
\hline Künzel, T. & Lhagvasuren, B. & Low, B. \\
\hline Kuroda, S. & $\mathrm{Li}, \mathrm{S}$. & Low, T. \\
\hline Kurt, F. & Li, W. & Lowrey, C. \\
\hline Kurtonur, C. & Libois, R. & Loy, A. \\
\hline Kutt, A. & Lidicker Jr., W. & Lu, W. \\
\hline Lahiri Choudhury, D. & Lillo, E. & Lü, Z. \\
\hline Laidre, K. & Lim, B.K. & Lucherini, M. \\
\hline Laker, J. & Lindenmayer, D. & Lumsden, L. \\
\hline Lamarque, F. & Linder, J. & Luna, L. \\
\hline
\end{tabular}


Lunde, D.

Lundie-Jenkins, G.

Lunn, N.

Lunney, D.

Lyenga, $A$.

Lynam, A.

Lynam, $T$.

Maas, B.

Mabee, $\mathrm{T}$.

Macdonald, A.

Macdonald, D.

MacKinnon, J.

MacLeod, C.

MacPhee, R.

Madhavan, A.

Maeda, K.

Maffei, L.

Maharadatunkamsi, D.

Maheswaran, G.

Maisels, F.

Malakar, M.

Malcolm, J.

Malpica, F.J.R.

Mancina, C.

Manh Ha, N.

Mann de Toledo, P.

Mannullang, B.

Manoharan, N.S.

Mantilla, $\mathrm{H}$.

Manullang, M.O.

Maran, $T$.

Maree, S.

Marimuthu, G.

Marinho-Filho, J.

Marini-Filho, O.

Marino, J.

Marker, L.
Marmontel, M.

Marsh, $\mathrm{H}$.

Marsh, L.

Marshall, A.

Marthy Rombang, W.

Martin, A.

Martin, E.

Martin, $\mathrm{R}$.

Martinez, J.

Martínková, N.

Martins da Silva Júnior, J.

Martyr, D.

Maryanto, I.

Marzetti, I.

Masoud, T.

Masseti, M.

Master, L.

Masters, P.

Matillano, J.

Matola, S.

Matson, J.

Matsumura, S.

Matthee, C.

Maude, G.

Mawson, $\mathrm{P}$.

Maxwell, A.

Mc Shea, B.

McCallum, $\mathrm{H}$.

McCarthy, $T$.

McCreery, $\mathrm{K}$.

McDonald, R.

McGraw, S.

McGuire, T.

McKenzie, G.

McKenzie, N.

McKinnon, J.

McLellan, B.
McNutt, J.

McShea, W.

Mead, J.

Mech, L.

Medhi, R.

Medina, A.

Medina, C.

Medina-Vogel, G.

Medlin, G.

Meegaskumbura, S.

Meena, V.

Mehlman, $\mathrm{P}$.

Meijaard, E.

Meinig, $\mathrm{H}$.

Menard, N.

Mendes, S.

Menkhorst, $\mathrm{P}$.

Menon, V.

Menzies, J.

Merino, $M$.

Meritt, D.

Meritt, $\mathrm{M}$.

Merker, S.

Mertzanidou, D.

Mesnick, S.

Meyers, D.

Mickleburgh, S.

Mignucci-Giannoni, A.

Mijiddorj, B.

Mildenstein, $\mathrm{T}$.

Miller, B.

Miller, J.

Milne, D.

Milner-Gulland, E.

Miquelle, D.

Mira, A.

Miranda, F. 
Misra, M.K.

Mistry, S.

Mitani, J.

Mitra, S.

Mitsain, G.

Miura, S.

Mix, $\mathrm{H}$.

Moehrenschlager, A.

Mohammed, O.

Molinari, J.

Monadjem, A.

Monkhbat, J.

Monkhtoghtokh, O.

Monkhtsog, B.

Monkhtuya, B.

Monkhzul, T.

Montenegro, $\mathrm{O}$.

Mooney, N.

Moore, J.

Moore, L.

Moores, N.

Morales-Jiménez, A.L.

Morefield, J.

Morgan, B.

Morgan, D.

Morris, $\mathrm{K}$.

Morrison, M.

Moseby, K.E.

Mostafa Feeroz, M.

Motokawa, M.

Mouna, M.

Moura, R.

Moyer, D.

Mudappa, D.

Mugisha, A.

Mukherjee, S.

Mukherji, S.
Mulavwa, M.

Muni, M.

Munkhzul, Ts.

Munks, S.

Munny, $P$.

Muñoz, A.

Muñoz, L.

Muñoz, Y.

Murakami, O.

Murdoch, J.

Murray, D.

Musser, G.

Mustari, A.

Nader, I.

Nadler, T.

Nagorsen, D.

Nagy, Z.

Nakamura, M.

Nameer, P.O.

Nandintsetseg, D.

Naranbaatar, G.

Naranjo, E.

Narayan, G.

Nash, S.

Nathan, P.T.

Nathar, K.

Natoli, A.

Naveda, A.

Ndunda, M.

Neelakantan, K.S.

Nekaris, A.

Nel, J.

Newby, J.

Newton, P.

Ngoc Thanh, V.

Nijman, V.

Nixon, S.
Noble, A.

Noblet, J.

Nolan, B.

Nomao, A.

Noronha, M.

Norris, S.

Northridge, S.

Noss, A.

Notarbartolo di Sciara, G.

Novarino, W.

Novaro, A.

Novellie, P.

Nurul Huda

Nusalawo, M.

Nyambayar, B.

Nyberg, D.

Nyhus, $\mathrm{P}$.

O'Corry-Crowe, G.

Oakwood, M.

Obradovitch, M.

Ochoa Graterol, J.

Ochoa, J.

Odhiambo, C.

O'Donnell, C.

O'Donovan, D.

Oguge, N.

Ohdachi, S.

Ojeda, R.

Oliveira, J.A.

Oliveira, T.G. de

Olivieri, G.

Olsen, $\mathrm{K}$.

Olson, A.

Olson, L.

Olsson, A.

Omasombo, V.

Ong, $\mathrm{P}$. 
Onon, Y.

Ordóñez Delgado, L.

Oshida, T.

Osokhjargal, D.

Otgonbaatar, M.

Ovsyanikov, N.

Oyuna, S.

Oyungerel, E.

Özkan, B.

Pacheco, S.

Pacheco, V.

Packer, C.

Packer, K.

Paddack, J.

Padmanabhan, $\mathrm{P}$.

Paglia, A.

Paguntalan, L.M.

Paisley, S.

Palacios, E.

Palka, D.

Palmeirim, J.

Palomares, F.

Pamaong, R.

Pandaranayaka, P.J.E.

Pardiñas, U.

Parnaby, $\mathrm{H}$.

Parr, J.W.K.

Parr, M.

Parra, G.

Passamani, M.

Passos, F.

Patel, E.

Pattanavibool, A.

Patton, J.

Paul, S.

Paunović, M.

Pavey, C.
Payan, E.

Payne, J.

Pearson, D.

Pedraza, S.

Pedregosa M.

Peeters, P.

Pei, K.C.J.

Pennay, M.

Percequillo, A.R.

Pereira, J.

Pérez, J.

Pérez, S.

Pergams, $\mathrm{O}$.

Perico M., D.

Perieras, A.

Perkin, A.

Perrin, M.

Perzanowski, K.

Peters, S.

Pethiyagoda, R.

Phillips, M.

Phuong, T.

Pilgrim, J.

Pillai, K.

Pimley, E.

Pine, $\mathrm{R}$.

Piñeda, C.

Pineda, J.

Pineda, W.

Pino, J.

Pinto, L.

Piovezan, U.

Pires Costa, L.

Pita, R.

Pitman, R.

Plowman, A.

Plumptre, A.
Pokheral, C.

Polechla, P.

Popper, K.

Porini, G.

Powell, J.

Poyarkov, A.

Pradhan, M.S.

Prasad Pokheral, C.

Princee, F.

Printes, R.

Priya, B.

Priya, K.P.

Priyono, A.

Pudyatmoko, S.

Puig, S.

Purchase, N.

Purevsuren, L.

Pushkar, K.

Qarqas, M.

Qisen, Y.

Queirolo, D.

Queiroz, H.

Querouil, S.

Qureshi, Q.

Rabarivola, J.

Rabearivelo, A.

Rabei, A.

Rabesihanaka, S.

Rabiei, A.

Rabotoarison, C.

Rachlow, J.

Radilofe, S.

Raghuram, $\mathrm{H}$.

Rahajanirina, L.

Rahelison, Y.

Raheriarisena, M.

Rahmani, A. 
Rainho, A.

Rajamani, N.

Rajaobelina, L.

Rajaobelina, S.

Rajaonhasoa, R.

Rajasekar, R.

Rakotoarijaona, J.

Rakotoarivelo, A.

Rakotoary, J.

Rakotobe, Z.

Rakotomanga, T.

Rakotondravony, D.

Rakotoniaina, J.

Rakotosamimanana, B.

Ralimanana, $\mathrm{H}$.

Ram, S.

Ramachandran, K.K.

Ramakantha, V.

Raman, T.R.S.

Ramangason, G.

Ramanoelina, $P$.

Ramaromisa, L.

Ramaswamy, G.

Ramayla, S.

Ramiarinjanahary, $\mathrm{H}$.

Ramiarison, C.

Ramilo, E.

Raminoarisoa, V.

Randall, D.

Randi, E.

Randriamanantsoa, $\mathrm{H}$.

Randrianarisoa, $\mathrm{F}$.

Randrianasolo, $\mathrm{H}$.

Randrianjafy, V.

Ranivo, J.

Rasamimanana, $\mathrm{H}$.

Rasamison, A.
Rasmussen, G.

Rasolonandrasana, B.

Ratnayeke, S.

Ratrimomanarivo, $\mathrm{F}$.

Ratsimbazafy, J.

Ratsirarson, J.

Raveloarinoro, G.

Ravelonandro, P.

Ravichandran, B.

Ravikumar, L.G.

Ravino, J.

Rawson, B.

Ray, J.

Rayaleh, $\mathrm{H}$.

Raynor, B.

Razafiarison, Z.

Razafilalao, N.

Razafimahatratra, E.

Razafimanahaka, H.J.

Razafimanantsoa, A.

Razafindrakoto, $\mathrm{Y}$.

Razafindralambo, G.

Read, A.

Read, J.

Reading, R.

Reardon, $\mathrm{T}$.

Reed, J.

Regidor, $\mathrm{H}$.

Reichel, J.

Reid, F.

Reinartz, G.

Reis, M.

Reizl, J.

Reyna, R.

Reyna-Hurtado, R.

Reynolds, $\mathrm{H}$.

Reynolds, V.
Rhind, S.

Rice, C.

Richard-Hansen, C.

Richards, G.

Richards, J.

Richards, N.

Richardson, M.

Riddle, $\mathrm{H}$.

Riga, $F$.

Rigaux, $\mathrm{P}$.

Ritchie, E.

Rivas, B.

Rivas-Pava, P.

Riveros, J.

Robbins, M.

Robbins, R.

Roberton, S.

Robichaud, W.

Robinson, $T$.

Rocha, N.

Rodden, M.

Rodrigues de Freitas, S.

Rodrigues, $\mathrm{F}$.

Rodríguez, A.

Rodriguez, J.

Rodriguéz-Herrera, $B$

Rodríguez-Luna, E.

Rodríguez-Mahecha, J.

Roemer, G.

Rogan, E.

Rojas-Bracho, L.

Romero, A.

Rookmaaker, K.

Roos, A.

Roos, C.

Rosel, P.

Rosenbaum, $\mathrm{H}$. 
Rosmarino, N.

Ross, G.

Ross, J.

Ross, S.

Rossi, R.

Rossiter, S.

Roth, E.

Roth, L.

Rovero, F.

Rübel, A.

Rubenstein, D.

Ruedas, L.

Ruiz-Olmo, J.

Rumiz, D.

Rumpler, Y.

Runcie, M.

Russell-Smith, J.

Saeki, M.

Saha, S.S.

Sahoo, S.K.

Salas, L.

Salazar-Bravo, J.

Saleh, M.

Salim, A.

Saltz, D.

Samba Kumar, N.

Samedi

Samiya, R.

Sampaio, E.

Samudio, R.

Sanchez Rojas, G.

Sánchez, J.

Sanderson, J.

Sano, A.

Santos, S.

Sarkar, S.K.

Sarker, S.U.
Sarmiento, E.E.

Sasaki, $\mathrm{H}$.

Savage, A.

Saw Htun

Saxon, M.

Schaller, G.

Scherlis, J.

Scheuering, E.

Schiavini, A.

Schliebe, S.

Schlitter, D.

Schreiber, A.

Schulz, M.

Schwitzer, C.

Schwitzer, N.

Scott, D.

Scott, M.

Sebastian, T.

Secada, L.

Secchi, E.

Sectionov

Sedlock, J.

Seedikkoya, K.

Sefass, $T$.

Semiadi, G.

Senacha, K.R.

Sepulveda, M.

Sequin, E.

Serena, M.

Sergelen, J.

Seri, L.

Serra, G.

Servheen, C.

Seryodkin, I.

Seydack, A.

Seyhan, G.

Shagdarsuren, $\mathrm{O}$.
Shah, N.

Shank, C.

Shar, S.

Sharifi, M.

Sharma, A.K.

Shedden, A.

Sheela, J.

Sheftel, B.

Shekelle, M.

Shenbrot, G.

Shepherd, C.

Sherwin, W.

Short, J.

Shoshani, $\mathrm{H}$.

Shreshtha, T.K.

Shugart, $\mathrm{H}$.

Shukkur, E.A.A.

Siex, K.

Siliwal, M.

Silva Jr., J. de S.

Silva, C.

Silva, G.

Silveira, L.

Simkins, G.

Simmons, N.

Simpson, L.

Sinaga, M.H.

Singadan, R.

Singaravelan, N.

Singh, M.

Singleton, I.

Sinha, A.

Sinha, R.

Sinha, Y.P.

Sinisterra Santana, J.

Siy, S.

Sliwa, A. 
Slooten, E.

Smit, $\mathrm{H}$.

Smith, B.

Smith, J.

Smith, $R$.

Sogbohossou, E.

Solanki, G.S.

Solari, S.

Solomon, S.P.R.

Somaweera, R.K.

Soriano, P.

Sousa, M.

Southgate, $R$.

Southwell, C.

Sovada, M.

Soy, J.

Sözen, M.

Spelman, L.

Spironello, W.

Spitzenberger, F.

Sreepada, K.S.

Srinivasulu, B.

Srivatsava, $P$.

St. Louis, A.

Start, T.

Steel, L.

Steinmetz, R.

Stephenson, P.

Stevens, K.

Stier, S.

Stokes, E.

Stone, G.

Strahan, R.

Strauss, M.

Streicher, U.

Struhsaker, S.

Struhsaker, T.
Stuart, C.

Stuart, T.

Stübbe, M.

Stuebing, $R$.

Sturm, M.

Suárez Mejía, J.

Suarez, L.

Subbotin, A.

Subirá, R.

Sugardjito, J.

Sugimura, K.

Sukhchuluun, $\mathrm{G}$.

Sukhchuluun, S.

Sukhtulga, S.

Sumardja, E.

Sunarto, S.

Sunderland-Groves, J.

Superina, M.

Supriatna, J.

Sussman, $R$.

Suyanto, A.

Suyanto, I.

Swanson, B.

Swarner, M.

Swe, K.M.

Tabao, M.

Tabaranza, B.

Taber, A.

Taei, S.

Taggart, D.

Takahaio, I.

Tallents, L.

Talmale, S.S.

Tanduyan, S.

Tannerfeldt, M.

Tatayah, V.

Tavares, V.
Taylor, A.

Taylor, C.

Taylor, $\mathrm{P}$.

Teale, $\mathrm{R}$.

Teclai, $\mathrm{R}$.

Teixeira de Moura, R.

Tej Kumar Shreshtha

Tejedor, A.

Telfer, W.

Teta, $\mathrm{P}$.

Thabah, A.

Thalmann, U.

Than Zaw

Thanh Hai, D.

Thapa, J.

Thompson, D.

Thompson, J.

Thomson, B.

Thouless, C.

Tikhonov, A.

Tilson, $\mathrm{R}$.

Timm, R.

Ting, N.

Ting, $\mathrm{T}$.

Tinnin, D.

Tizard, R.

Tokida, K.

Tooze, Z.

Torres, D.

Traeholt, C.

Traylor-Holzer, K.

Trillmich, F.

Trocchi, V.

Trujillo, F.

Truong Son, N.

Tsendjav, D.

Tsogbadrakh, M. 
Tsogt, S.

Tungalagtuya, Kh.

Turvey, S.

Tutin, C.

Tuya, $\mathrm{T}$.

Tyagi, P.C.

Tyson, M.

Urban, J.

Urbani, B.

Usukhjargal, D.

Valderrama, C.

Valdespino, C.

Valdez, R.

Valente, M.

Valesco, M.

Valezco, P.

Van Bressem, M.

van Daele, $P$.

van der Straeten, E.

Van Dyck, S.

van Gruissen, J.

van Jaarsveld, A.

van Lavieren, E.

van Manen, $F$.

Van Nhuan, N.

Van Rompaey, $\mathrm{H}$.

Van Rompaey, J.

van Schaik, C.

Van Waerebeek, K.

van Weenen, J.

Vanitharani, J.

Varela, D.

Vargas, J.

Vaslin, M.

Vázquez, E.

Velazco, P.

Velez-Liendo, X.
Velilla, M.

Venkataraman, A.

Verheyen, W.

Vermeer, J.

Veron, G.

Vidal, O.

Viddi, $F$.

Vieira, E.

Vieira, M.

Vila, A.

Villalba, L.

Vivar, E.

Vizcaino, S.

Vogel, P.

Vogliotti, A.

Vohralík, V.

Volahy, A.

Vololomboahangy, $\mathrm{R}$.

von Arx, M.

Voss, $\mathrm{R}$.

Vu Dinh, $T$.

Vuthy, L.

Wacher, $\mathrm{T}$.

Wade, $P$.

Wagner, A.

Wahl, R.

Waldemarin, $\mathrm{H}$.

Walker, S.

Wallace, $R$.

Walsh, $P$.

Walston, J.

Wang, D.

Wang, J.

Wang, S.

Wang, $X$.

Ward, D.

Warguez, D.
Watanabe, M.

Waters, S.

Watson, A.

Watson, M.

Watts, C.

Wayne, A.

Wayne, R.

Weber, M.

Weerasinghe, A.N.

Weinberg, $P$.

Weksler, M.

Wells, $R$.

Wen, $\mathrm{X}$.

Westerman, M.

Weyandt, S.

Wheeler, J.

Wheeler, P.

Whitaker Jr., J.O.

Whitehead, $\mathrm{H}$.

Whittaker, D.

Wibisono, $\mathrm{H}$.

Wich, S.

Widmann, I.

Widmann, P.

Wiesel, I.

Wiig, $\varnothing$.

Wijayanto, I.

Wijeyamohan, S.

Wikramanayake, E.

Wiles, G.

Wilhelmi, F.

Williams, D.

Williams, J.

Williams, $R$.

Williams, S.

Willig, M.

Willson, $\mathrm{K}$. 
Wilmé, L.

Wilmer, J.

Wilson, B.

Wilson, D.E.

Wilson, $M$.

Wilting, A.

Winter, J.

Woinarski, J.

Wong, G.

Wong, S.

Woodman, N.

Woodroffe, R.

Woolley, P.

Wozencraft, C.

Wright, D.

Wright, $P$.

Würsig, B.

Xia, W.

Xuan Canh, L.

Xuelong, J.

Yalden, D.

Yamada, F.

Yang, S.C.

Yanling, S.

Yapa, W.

Yara Ortiz, D.

Yardi, D.K.

Yeniyurt, C.

Yensen, E.

Yigit, N.

Ying, W.

Yingxiang, W.

Yohannes, $\mathrm{H}$.

Yokohata, Y.

Yom-Tov, Y.

Yoneda, M.

Yongcheng, L.
Yongzu, Z.

Yonzon, P.

Yoxon, G.

Yoxon, $P$.

$\mathrm{Yu}, \mathrm{W}$.

Yustian, I.

Zafir, A.

Zagorodnyuk, I.

Zahler, P.

Zeballos, $\mathrm{H}$.

Zeballos, N.

Zeballos, Z.

Zemanova, B.

Zerbini, A.

Zhou, K.

Ziaie, $\mathrm{H}$.

Zima, J.

Zimmermann, W.

Zortea, M.

Zuercher, G. 